\title{
A STUDY ON THE PROSPECT OF HYDROPOWER TO HYDROGEN IN NEPAL
}

Aiming Zhou, Wei Zhou, and Pushkar Manandhar

NO. 73

August 2020

\section{ADB SOUTH ASIA WORKING PAPER SERIES}





\section{ADB South Asia Working Paper Series}

\section{A Study on the Prospect of Hydropower to Hydrogen in Nepal}

Aiming Zhou, Wei Zhou, and Pushkar Manandhar

No. 73 | August 2020
Aiming Zhou is senior advisor at the Office of the Vice President (Operations 1), Asian Development Bank (ADB). Wei Zhou is a doctoral researcher at the Energy Policy Research Group, University of Cambridge. Pushkar Manandhar is senior project officer (energy) at the South Asia Department, ADB.

The authors thank Anthony Jude and Toru Ito for reviewing and providing helpful comments on the paper. 
(C) 2020 Asian Development Bank 6 ADB Avenue, Mandaluyong City, 1550 Metro Manila, Philippines

Tel +632 8632 4444; Fax +63286362444

www.adb.org

Some rights reserved. Published in 2020.

Printed in the Philippines

ISSN 2313-5867 (print), 2313-5875 (electronic)

Publication Stock No. WPS200218-2

DOI: http://dx.doi.org/10.22617/WPS200218-2

The views expressed in this publication are those of the authors and do not necessarily reflect the views and policies of the Asian Development Bank (ADB) or its Board of Governors or the governments they represent.

ADB does not guarantee the accuracy of the data included in this publication and accepts no responsibility for any consequence of their use. The mention of specific companies or products of manufacturers does not imply that they are endorsed or recommended by ADB in preference to others of a similar nature that are not mentioned.

By making any designation of or reference to a particular territory or geographic area, or by using the term "country" in this document, $A D B$ does not intend to make any judgments as to the legal or other status of any territory or area.

This work is available under the Creative Commons Attribution 3.0 IGO license (CC BY 3.0 IGO) https://creativecommons.org/licenses/by/3.0/igo/. By using the content of this publication, you agree to be bound by the terms of this license. For attribution, translations, adaptations, and permissions, please read the provisions and terms of use at https://www.adb.org/terms-use\#openaccess.

This CC license does not apply to non-ADB copyright materials in this publication. If the material is attributed to another source, please contact the copyright owner or publisher of that source for permission to reproduce it. ADB cannot be held liable for any claims that arise as a result of your use of the material.

Please contact pubsmarketing@adb.org if you have questions or comments with respect to content, or if you wish to obtain copyright permission for your intended use that does not fall within these terms, or for permission to use the ADB logo.

The ADB South Asia Working Paper Series is a forum for ongoing and recently completed research and policy studies undertaken in $A D B$ or on its behalf. It is meant to enhance greater understanding of current important economic and development issues in South Asia, promote policy dialogue among stakeholders, and facilitate reforms and development management.

The ADB South Asia Working Paper Series is a quick-disseminating, informal publication whose titles could subsequently be revised for publication as articles in professional journals or chapters in books. The series is maintained by the South Asia Department. The series will be made available on the ADB website and on hard copy.

Corrigenda to ADB publications may be found at http://www.adb.org/publications/corrigenda.

Notes:

In this publication, "\$" refers to United States dollars. 


\section{CONTENTS}

TABLES AND FIGURES iv

ABSTRACT

ABBREVIATIONS vii

WEIGHTS AND MEASURES viii

$\begin{array}{llr}\text { I. } & \text { INTRODUCTION } & 1\end{array}$

\begin{tabular}{l|r} 
II. & ELECTRICITY SECTOR OF NEPAL
\end{tabular}

$\begin{array}{ll}\text { III. } & 5\end{array}$

$\begin{array}{llr}\text { IV. } & \text { TRANSPORT SECTOR OF NEPAL } & 8\end{array}$

$\begin{array}{ll}\text { V. HYDROGEN AS A POTENTIAL OPTION } & 10\end{array}$

VI. POSSIBLE HYDROGEN PRODUCTION IN NEPAL 12

VII. POTENTIAL HYDROGEN VALUE CHAIN IN NEPAL 14

VIII. COST ANALYSIS OF HYDROGEN VALUE CHAIN

A. Production Cost 15

B. Storage and Transportation Costs 19

C. Cost of Hydrogen for Electricity Generation and Storage 21

IX. POTENTIALS OF “HYDROPOWER-TO-X” IN NEPAL 22

$\begin{array}{ll}X . & \text { CONCLUDING REMARKS AND NEXT STEPS }\end{array}$

$\begin{array}{lr}\text { REFERENCES } & 28\end{array}$ 


\section{TABLES AND FIGURES}

\section{TABLES}

1 Techno-Economic Characteristics of Alkaline, Proton Exchange Membrane, and Solid Oxide Electrolysis Cells

2 Calculation of Hydrogen Production from Surplus Hydropower

\section{FIGURES}

1 Total Primary Energy Supply by Source, 2017

2 Total Final Consumption by Source, $2017 \quad 2$

3 Peak Demand versus Installed Capacity, 1997-2017 3

4 Load Forecast from 2019 to $2040 \quad 4$

5 Total Final Energy Consumption by Sector, 2017

6 Final Energy Consumption by Source of Residential Sector, Industry Sector, 6 and Transport Sector, 2017

7 Oil Products Final Consumption by Sector, 1990-2017 7

8 Share of Carbon Dioxide Emissions by Various Energy End-Use Sectors 7

9 Vehicle Registration Trend in Nepal from $2000 \quad 8$

10 Carbon Dioxide Emissions from Various Land Transport Modes 9

11 Renewables to Power 11

12 Renewables to Mobility 12

13 Principles of Electrolysis 13

14 Potential Hydrogen Value Chain in Nepal 15

15 Capital Expenditure Reduction Upon Use of Multistack Systems 16

16 The Impact of Load Factor and Electricity Price on Levelized Cost 17 of Hydrogen Production

17 Dynamic Impact of Electrolyzer Load Factor and Electricity Cost on Levelized Cost 17 of Hydrogen Production

18 Levelized Cost of Hydrogen Production of Electrolysis Using Surplus Electricity 18 Compared to Alternatives in 2050

19 Levelized Cost of Hydrogen Storage and Typical Storage Duration, 2019 19

20 Cost of Hydrogen Transmission by Pipeline 20

21 Cost of Hydrogen Distribution by Various Means 21

22 Levelized Costs of Electricity Generation by Hydrogen-Based Technologies 21 
23 The Impacts of Discharge Duration and Electricity Input Cost on Levelized Costs of Electricity Storage

24 Annual Electricity Generated by Hydropower and Hydrogen Re-Electrification Under Three Scenarios

25 Annual Electricity Generation from Hydrogen and its Share in Forecasted Electricity Demand 


\begin{abstract}
Nepal faces a critical energy crisis due to an acute shortage of electricity and fuel supply, despite its abundant hydropower resources that have remained largely undeveloped. The country's heavy dependence on energy imports, inadequate storage, and limited diversity of domestic electricity generation sources present critical challenges to its energy security. Meanwhile, Nepal is among the countries that are most vulnerable to climate change. With hydrogen recently emerging as a promising solution within the dynamically developing global energy landscape, this paper attempts to explore the prospect of hydrogen application for the unique context of Nepal where surplus electricity generated by hydropower during wet season, which otherwise would have been curtailed, could potentially be converted to hydrogen for electricity regeneration to meet the demand during dry season and/or electrifying and decarbonizing its major energy end-use sectors such as transport sector. The plausible hydrogen value chains are discussed and the potentials of the hypothetical hydropowerto-power and hydropower-to-mobility pathways are estimated. This preliminary study is expected to help raise the awareness of policymakers and serve as a baseline for further investigation into hydrogen opportunities in Nepal and possibly in other developing countries with rich indigenous energy resources and facing similar energy-related challenges.
\end{abstract}

Keywords: Nepal, Hydropower, Seasonality, Surplus, Hydrogen 


\section{ABBREVIATIONS}

$\begin{array}{ll}\text { ADB } & \text { Asian Development Bank } \\ \text { ALK } & \text { alkaline } \\ \text { CAPEX } & \text { capital expenditure } \\ \text { CCGT } & \text { combined-cycle gas turbine } \\ \text { CO }_{2} & \text { carbon dioxide } \\ \text { DMC } & \text { developing member country } \\ \text { FCEV } & \text { fuel cell electric vehicle } \\ \text { FY } & \text { fiscal year } \\ \text { GHG } & \text { greenhouse gas } \\ \text { IEA } & \text { International Energy Agency } \\ \text { IPP } & \text { independent power producer } \\ \text { IRENA } & \text { International Renewable Energy Agency } \\ \text { LCOH } & \text { levelized cost of hydrogen } \\ \text { NEA } & \text { Nepal Electricity Authority } \\ \text { NREL } & \text { National Renewable Energy Laboratory } \\ \text { PEM } & \text { proton exchange membrane } \\ \text { SOEC } & \text { solid oxide electrolysis cells } \\ \text { VAT } & \text { value-added tax }\end{array}$




\section{WEIGHTS AND MEASURES}

$\begin{array}{ll}\mathrm{GW} & \text { gigawatt } \\ \mathrm{GWh} & \text { gigawatt-hour } \\ \mathrm{kgH}_{2} & \text { kilogram of hydrogen } \\ \mathrm{km} & \text { kilometer } \\ \mathrm{ktoe} & \text { kiloton of oil equivalent } \\ \mathrm{kWe} & \text { kilowatt-electric } \\ \mathrm{kWh} & \text { kilowatt hour } \\ \mathrm{MtCO}_{2} \mathrm{e} & \text { metric ton of carbon dioxide equivalent } \\ \mathrm{MtH}_{2} & \text { million tons of hydrogen } \\ \mathrm{Mtoe} & \text { million tons of oil equivalent } \\ \mathrm{MW} & \text { megawatt } \\ \mathrm{MWh} & \text { megawatt-hour }\end{array}$




\section{INTRODUCTION}

1. A least developed, mountainous, and landlocked country-Nepal is facing critical energy crisis due to acute shortage of electricity and fuel supply, despite its abundant hydropower resources that have remained largely undeveloped. Currently, Nepal is among the countries that are most vulnerable to climate change and its effects. Efforts are needed to curb fossil fuel dependency and carbon emissions from major energy end-use sectors of its economy, such as the transport sector, which can be developed towards electrification and thus decarbonization. This study attempts to explore the prospect of applying hydrogen in the specific context of Nepal. It starts with a brief overview of Nepal's electricity sector and transport sector, which are both likely to make a case for hydrogen application in Nepal. This publication includes a description of the potential hydrogen value chains in Nepal, which are technically based on producing hydrogen from water and electricity generated by surplus hydropower. It also provides a brief cost analysis of the hydrogen supply chain, estimating the potentials of the hypothetical "hydropowerto-power" and "hydropower-to-mobility" pathways in Nepal. Overall, this preliminary study aims to serve as a baseline for further detailed studies on hydrogen deployment in Nepal and in other developing member countries (DMCs) that have abundant renewable resources but have no or limited progress in hydrogen-related initiatives.

\section{ELECTRICITY SECTOR OF NEPAL}

2. Nepal's primary energy supply is dominated by biofuels and waste, which are in the form of firewood, agricultural waste, and animal dung (Asian Development Bank [ADB] 2017). Other main sources of primary energy include oil products, coal, and hydropower. The total primary energy supply of Nepal reached 13.3 million tons of oil equivalent (Mtoe) in 2017, in which biofuels and waste accounted for $73.71 \%$ (Figure 1). As for total final energy consumption in the same year, the share of electricity was as low as 3.66\% (Figure 2). Over $99 \%$ of total electricity generation in Nepal was by hydropower (International Energy Agency [IEA] 2019b).

Figure 1: Total Primary Energy Supply by Source, 2017

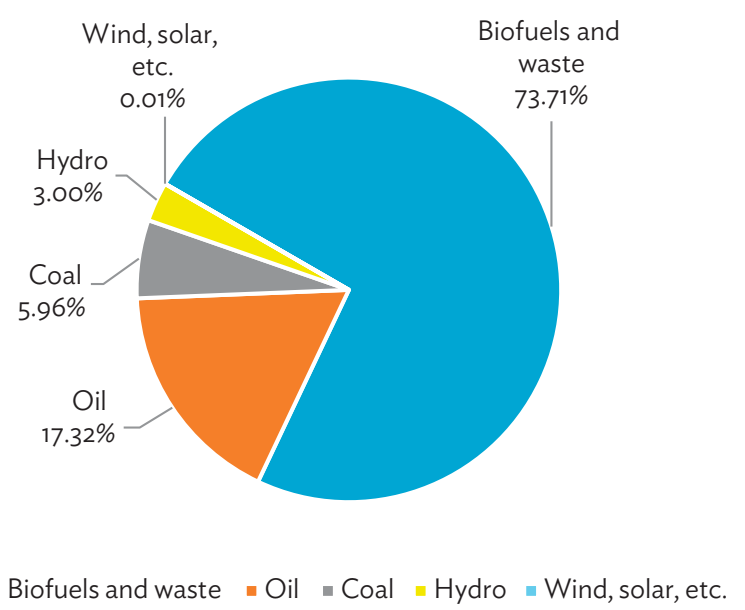

Source: International Energy Agency (IEA). 2019. Data and Statistics. https://www.iea.org/data-and-statistics. 
Figure 2: Total Final Consumption by Source, 2017

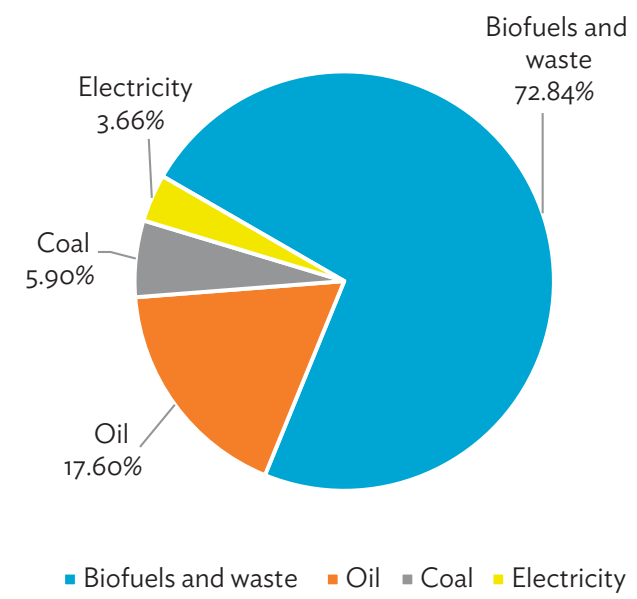

Source: IEA. 2019. Data and Statistics. https://www.iea.org/data-and-statistics.

3. The low share of electricity in total final energy consumption clearly indicates that Nepal faces significant supply constraints in its electricity sector, despite its rich hydro resources. The country has a hydropower potential of 83,000 megawatts (MW) and commercially exploitable hydropower generation potential of approximately 42,000 MW (ADB 2017; Water and Energy Commission Secretariat 2017). However, by the end of fiscal year (FY) 2019, ' the total installed capacity of Nepal's hydropower plants was at 1,113.48 MW (Nepal Electricity Authority [NEA] 2019), accounting for less than 2.5\% of the total commercially exploitable potential. Between 2008 and 2018, Nepal has only added about 550 MW of hydropower generation capacity (Shrestha 2017; NEA 2019). Key reasons underlying the slow progress of hydropower development include: (i) inadequate planning and investment in generation, transmission, and distribution capacity development; (ii) concerns about the ability of NEA to honor take-or-pay contract obligations; and (iii) delays in project development, due partly to inadequate legal and regulatory framework (ADB 2017).

4. The current installed capacity of 552.70 MW owned by NEA and 560.78 MW owned by private independent power producers (IPPs), were not sufficient to meet the peak demand in FY2019 that reached 1,508 MW (NEA 2019). This situation, wherein the total installed capacity was substantially lower than the peak demand, has remained consistent for about a decade since 2009, with the shortfall appearing as gradually increasing (Figure 3). The total installed generation capacity has grown steadily from $706 \mathrm{MW}$ in 2011 to $856 \mathrm{MW}$ in 2016-an annual average of 3.5\%. The peak demand, however, grew even faster during the same period, from $946.10 \mathrm{MW}$ to 1,385.30 MW, indicating an annual average of 7.7\% (ADB 2017; NEA 2019). Since most of the existing capacity in Nepal are run-of-the-river hydropower plants, the electricity generation is characterized by high fluctuation and seasonality. Therefore, the shortfall in power capacity is particularly critical during the dry winter season with significant decrease in glacial water flows that reduce the use of installed generation capacity by two-thirds (World Bank 2019a). This has resulted in daily load shedding of up to 11 hours during the dry months of January to April (ADB 2017). With increased electricity imports from India and improved management of existing generation, the load shedding issue was gradually resolved (World Bank 2019a). Since May 2018, Nepal has realized full eradication of the decade-long load shedding from the entire country through integrated resource planning including domestic generation, imports and efficient demand-side management (NEA 2018, 2019).

\footnotetext{
The fiscal year (FY) of the Government of Nepal ends on 15 July. "FY" before a calendar year denotes the year in which the fiscal year ends, e.g., FY2019 ends on 15 July 2019.
} 
Figure 3: Peak Demand versus Installed Capacity, 1997-2017

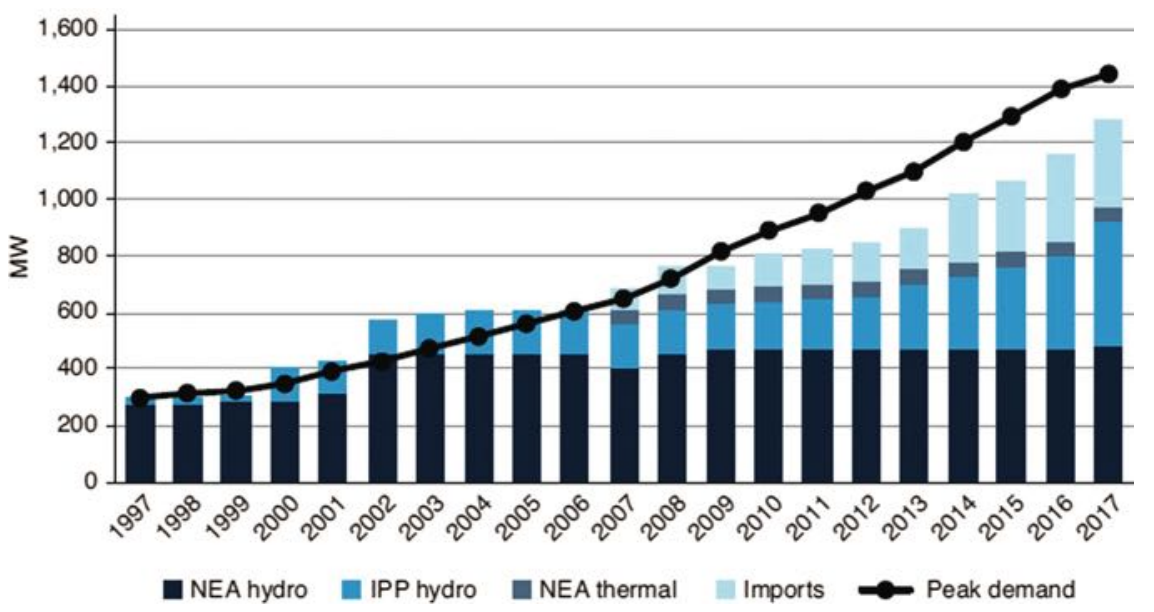

IPP = independent power producers, MW = megawatt, NEA = Nepal Electricity Authority.

Source: World Bank. 2019a. Nepal Energy Infrastructure Sector Assessment. http://documents.worldbank.org/curated/ en/592481554093658883/pdf/Nepal-Energy-Infrastructure-Sector-Assessment.pdf.

5. Despite the achievement in eradicating load shedding, Nepal continues to suffer from the adverse impacts of inadequate and unreliable electricity supply. While Nepal's rate of electrification (both on-grid and off-grid) has increased rapidly from 73.9\% in 2012 to 95.5\% in 2017 (World Bank $2019 b$ ), the actual consumption of electricity remains low due to severe constraints of electricity supply, which fails to keep up with the sharp rise in demand. In Nepal's energy mix, which is dominated by traditional biomass and imported petroleum, electricity accounts for a very minor share (ADB 2017). The total energy consumption of Nepal in 2013 was equivalent to 10,173 kilotons of oil equivalent (ktoe), to which electricity contributed about 3\% (Oxford Policy Management 2017). By the end of 2017, the share of electricity only marginally increased to $3.66 \%$ (IEA 2019b). The low consumption of electricity and the minor share of electricity consumption in Nepal's total energy demand are very likely to remain the trend over the medium term. As forecasted by ADB (ADB 2013), Nepal's electricity consumption in 2035 will be 0.9 Mtoe, accounting for only $5.4 \%$ of its total final energy demand despite the country's large hydropower potential. On a per capita basis, the electricity consumption has been increasing only marginally, from in 102.5 kilowatt-hour (kWh) per year in 2010 to $197 \mathrm{kWh}$ per year in 2017, a level equivalent to approximately $49 \%$ of Bangladesh ( $402 \mathrm{kWh}$ ), $28 \%$ of Sri Lanka $(712 \mathrm{kWh}$ ), 21\% of India (947 kWh), 4.3\% of the People's Republic of China (4,546 kWh), and $6.3 \%$ of the World on average (3,152 kWh) in 2017 (IEA 2019c). Despite an accelerated increase by over 22\% from 2017 to 2018, the absolute level of $245 \mathrm{kWh}$ per capita (NEA 2019) remains very low as compared to other economies in the region. The severely constrained supply of electricity has had significantly adverse impact on Nepal's social and economic development (World Bank 2019a).

6. To address the electricity supply constraint, NEA has been accelerating the development and implementation of NEA-owned hydropower plants. In FY2019, NEA's hydropower plants generated 2,548.11 gigawatt-hour (GWh), an increase of 10.39\% over the previous year, achieving a record high (NEA 2019). The participation of the private sector has also been facilitated through power purchase agreements (PPAs) between NEA and IPPs. By end of FY2019, a pipeline of 340 PPAs were signed with various IPPs for a combined installed capacity of 6,044.05 MW (NEA 2019). Moving forward, as set out in Nepal's White Paper on Energy, Water Resources and Irrigation Sector's Status and Roadmap for the Future 
Figure 4: Load Forecast from 2019 to 2040

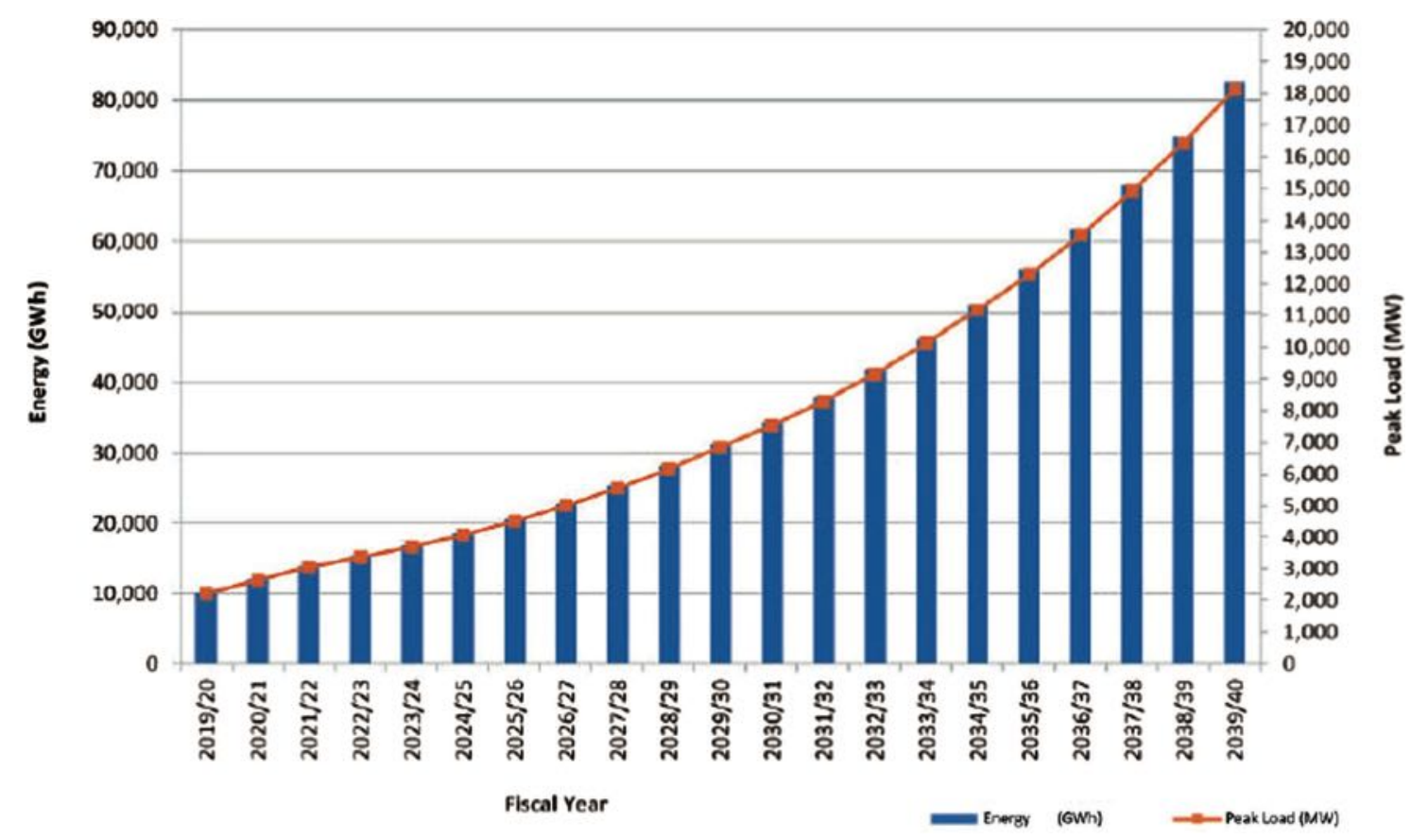

GWh = gigawatt-hour, MW = megawatt.

Source: Nepal Energy Authority (NEA). 2019. Annual Report 2018/19. https://www.nea.org.np/admin/assets/uploads/ supportive_docs/annual_report_2076.pdf.

("the White Paper") issued in May 2018, the total installed hydropower generation capacity in Nepal is planned to reach 3 gigawatt (GW) in 3 years, $5 \mathrm{GW}$ in 5 years, and $15 \mathrm{GW}$ in 10 years (Ministry of Energy Water Resources and Irrigation 2018). The White Paper also sets the target of increasing the per capita electricity consumption to $1,500 \mathrm{kWh}$ in 10 years. However, given the fact that the total installed capacity by end of FY2019 was only 1,113.48 MW and also the fact that the capacity of projects that had achieved financial closure and were being developed by IPPs was only 2,613.90 MW, it is considered highly unlikely that the immediate target of $3 \mathrm{GW}$ in 2021 can be achieved in full, let alone other ambitious targets in 5 or 10 years. The gap can be attributed to various factors, including underinvestment, external shocks, trade blockade, and weak implementation capacity (World Bank 2019a). This presents critical challenges to the target of meeting peak demand over the short- to medium-term, forecasted to increase from 2,225 MW in 2020, to 6,848 MW in 2030, and further to 18,137 MW in 2040 (Figure 4).

7. Meanwhile, to bridge the gradually widening supply-demand gap, electricity has been imported from India on a regular basis. From 2011 to 2016, the share of imported electricity in Nepal's total electricity supply increased from 18\% to 35\% (ADB 2017). In FY2019, the total electricity imported from India increased to 2,813 GWh, accounting for $29 \%$ in total available electricity in NEA's system (NEA 2019). Importing electricity from India is expected to continue as a technically feasible and costeffective way of meeting increasing demand during the dry season in Nepal. In the meanwhile, given the prospect of surplus electricity in the wet season in $\mathrm{Nepal}$, there is great potential and economic rationale for Nepal to export electricity to neighboring countries such as India during the wet season. In FY2019, this was realized with 34.74 GWh exported to India. Cross-border electricity trading can be a win-win option for Nepal to improve the efficiency and reliability of its electricity system and meet its increasing electricity demand in a cost-effective way. While NEA has identified cross-border power trading as one 
of the priorities to pursue (NEA 2019), the development of large-scale export-oriented hydropower projects has not been successful due to failure in reaching financial closure (World Bank 2019a). The attainment of the potential of cross border power trading depends on substantial investments and the establishment of enabling institutional, policy, and regulatory framework to facilitate trading.

\section{ENERGY CONSUMPTION BY SECTOR}

8. Nepal's final energy consumption in 2017 (Figure 5), according to IEA statistics, the residential sector accounted for the largest share (75.75\%), having consumed 10,153 kilotons of oil equivalent (ktoe). The transport sector was the second, and the industry sector was the third largest energy consumer, accounting for $11.69 \%$ and $7.80 \%$, respectively. While the shares of transport and industry sectors remain minor as compared to the residential sector, these sectors have been growing fast and their energy consumptions have been increasing accordingly. In particular, the transport sector of Nepal has been experiencing fast development over recent years, with its energy consumption increasing from 637 ktoe in 2010 to 1,567 ktoe in 2017 (IEA 2019b).

\section{Figure 5: Total Final Energy Consumption by Sector, 2017}

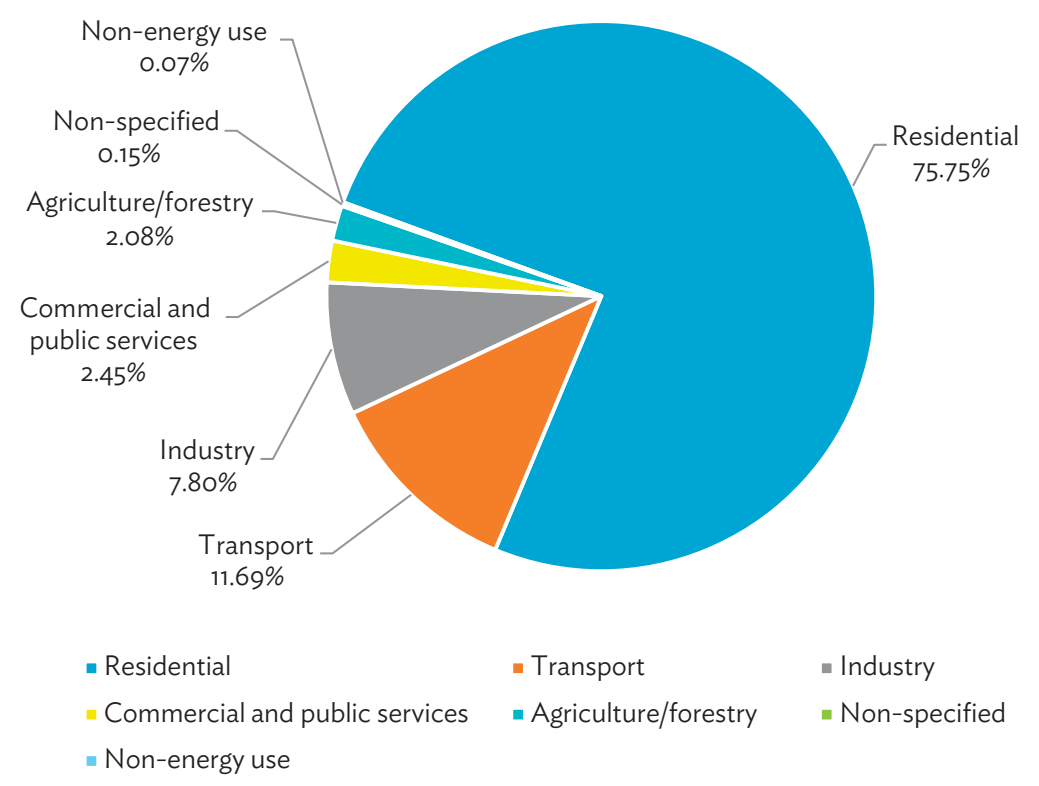

Source: IEA. 2019b. Data and Statistics. https://www.iea.org/data-and-statistics.

9. Figure 6 shows the final energy consumption by source of the three sectors in 2017. While nearly $95 \%$ of the energy consumption by the residential sector was met by indigenous biofuels and waste resources available in the country, the industry and transport sectors were heavily dependent on imported coal and oil products. Compared to the industry sector, the transport sector was more dependent on energy import and therefore more vulnerable to potential disruptions to energy supply, because (i) the consumption of imported oil products by transport sector in 2017 was 1,566 ktoe, nearly double that of the consumption of imported coal by industry sector in 2017; and (ii) with imported oil 


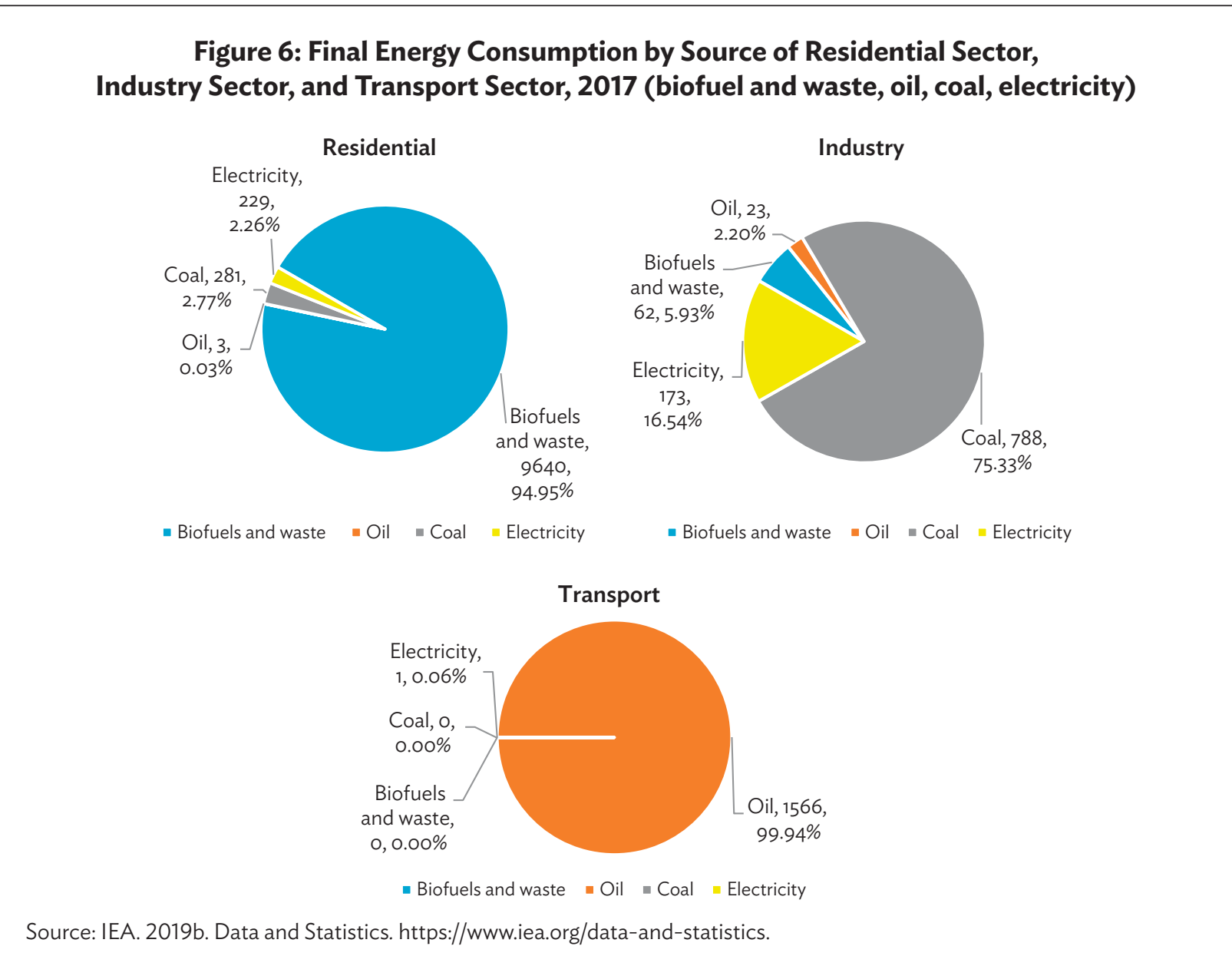

products accounting for nearly $100 \%$ of its energy consumption, the transport sector had significantly lower level of energy diversification than the industry sector.

10. The share of oil products consumption by the transport sector in total consumption of oil products by all sectors of Nepal has been increasing considerably over the past decade (Figure 7). From 2007 to 2017, this share increased from 49\% to 67\% (IEA 2019b). As the energy consumption of the transport sector is expected to keep increasing (Water and Energy Commission Secretariat 2013; ADB 2017), the sector's high demand for oil products and high degree of dependence on imports of oil products are highly likely to remain under the existing policy framework. Such a situation, coupled with inadequate oil products storage capacity of Nepal (Water and Energy Commission Secretariat 2013; ADB 2017), will present significant challenges to Nepal's efforts to improve energy security.

11. The combustion of fuels generates greenhouse gas (GHG) emissions. According to Nepal's GHG Inventory Report for Third National Communication (Ministry of Population and Environment 2017), the total GHG emissions from Nepal's energy consumption in 2011 reached 14.7 metric tons of carbon dioxide equivalent $\left(\mathrm{MtCO}_{2} \mathrm{e}\right)$, of which transport sector accounted for $12 \%$. Excluding methane $\left(\mathrm{CH}_{4}\right)$ and nitrous oxide $\left(\mathrm{N}_{2} \mathrm{O}\right)$ emissions caused by combusting biomass by commercial, institutional and residential sectors, the total carbon dioxide $\left(\mathrm{CO}_{2}\right)$ emissions from Nepal's energy end-use sectors in 2011 was $4.67 \mathrm{MtCO}_{2} \mathrm{e}$, of which transport sector accounted for 36.5\% (Figure 8). This share further increased to $45.4 \%$ in 2017 (IEA 2019b). 
Figure 7: Oil Products Final Consumption by Sector, 1990-2017

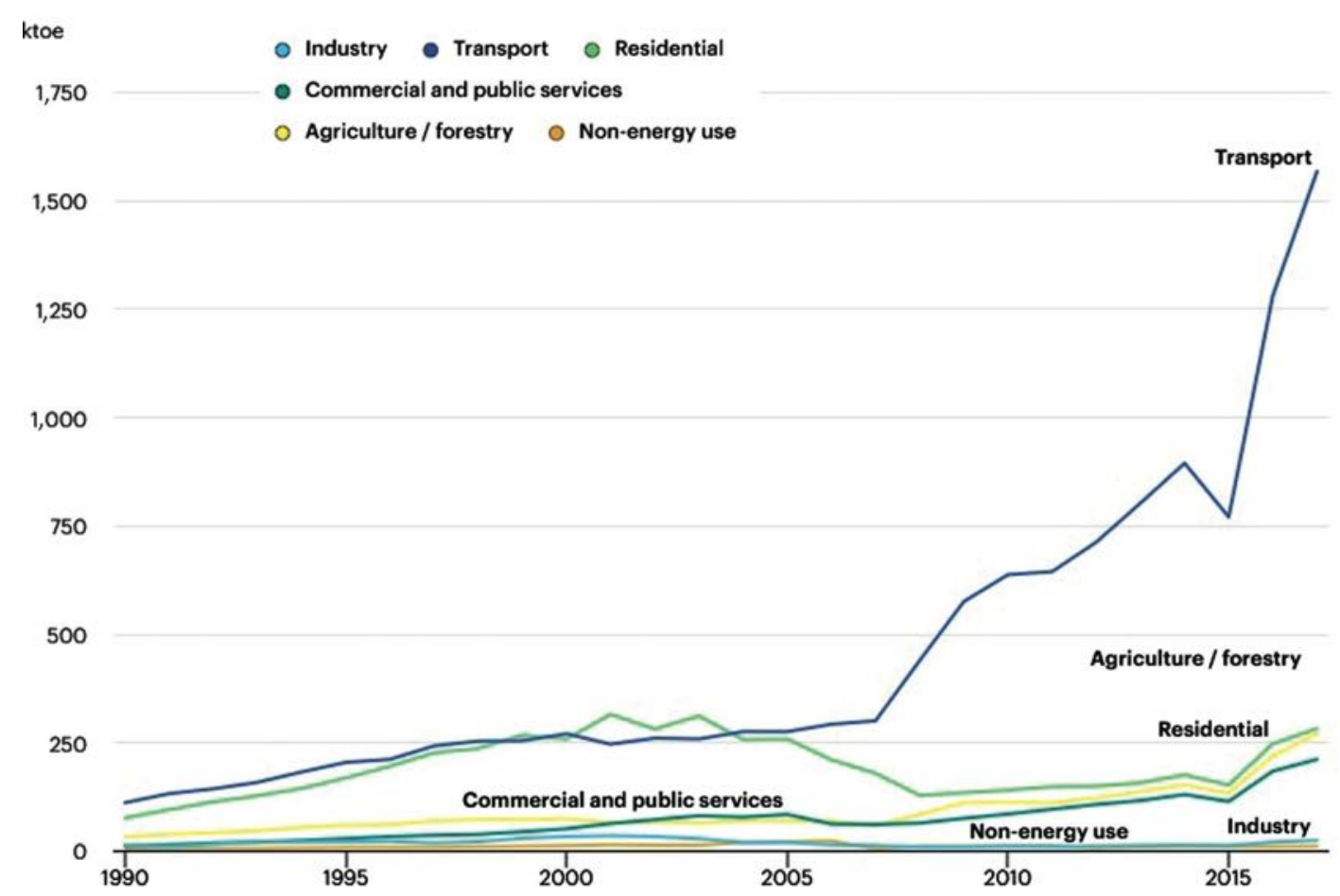

ktoe $=$ kiloton of oil equivalent.

Source: IEA. 2019b. Data and Statistics. https://www.iea.org/data-and-statistics.

\section{Figure 8: Share of Carbon Dioxide Emissions by Various Energy End-Use Sectors}

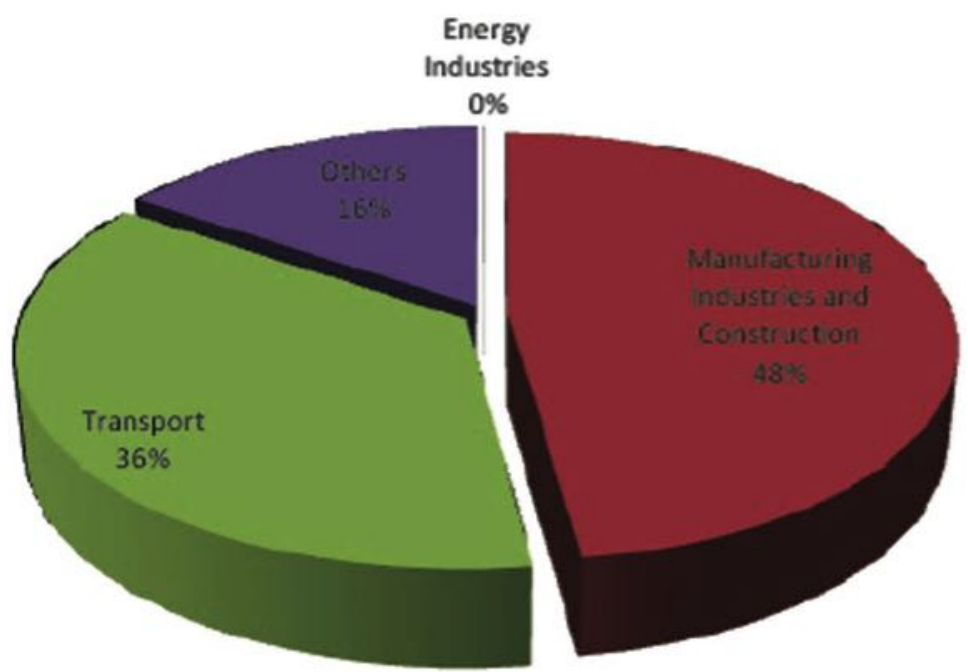

Source: Government of Nepal, Ministry of Population and Environment. 2016. Nationally Determined Contributions.

12. All these facts signify the critical challenges facing Nepal's transport sector and therefore point to the need to prioritize transport sector on Nepal's climate and energy agenda. From this perspective, this paper chooses transport sector as a key energy end-use sectors of Nepal for preliminary analysis of potential hydrogen application. 


\section{TRANSPORT SECTOR OF NEPAL}

13. Since 2000, Nepal's transport sector has experienced significant growth. Road is the predominant mode of transportation, accounting for $90 \%$ of passenger and freight transportation. While the registration of bus, minibus, and heavy trucks increased gradually over time, the registration of passenger cars and sport utility vehicles (SUVs) increased significantly, from 8,510 in 2011 to 28,361 in 2016 (Figure 9). The main fuel consumed by Nepal's transport sector is diesel, which is followed by petrol and liquified petroleum gas. Figure 10 shows the contribution of various subsectors of Nepal's transport sector to the sector-wide $\mathrm{CO}_{2}$ emissions. The heavy commercial vehicles, including truck, tanker, and lorry, were the largest emitters. The second largest emitters were composed of passenger cars, SUVs, and pickup trucks, emissions of which were approximately $90 \%$ of heavy commercial vehicles. Buses (including minibuses) were the third largest emitters.

Figure 9: Vehicle Registration Trend in Nepal from 2000

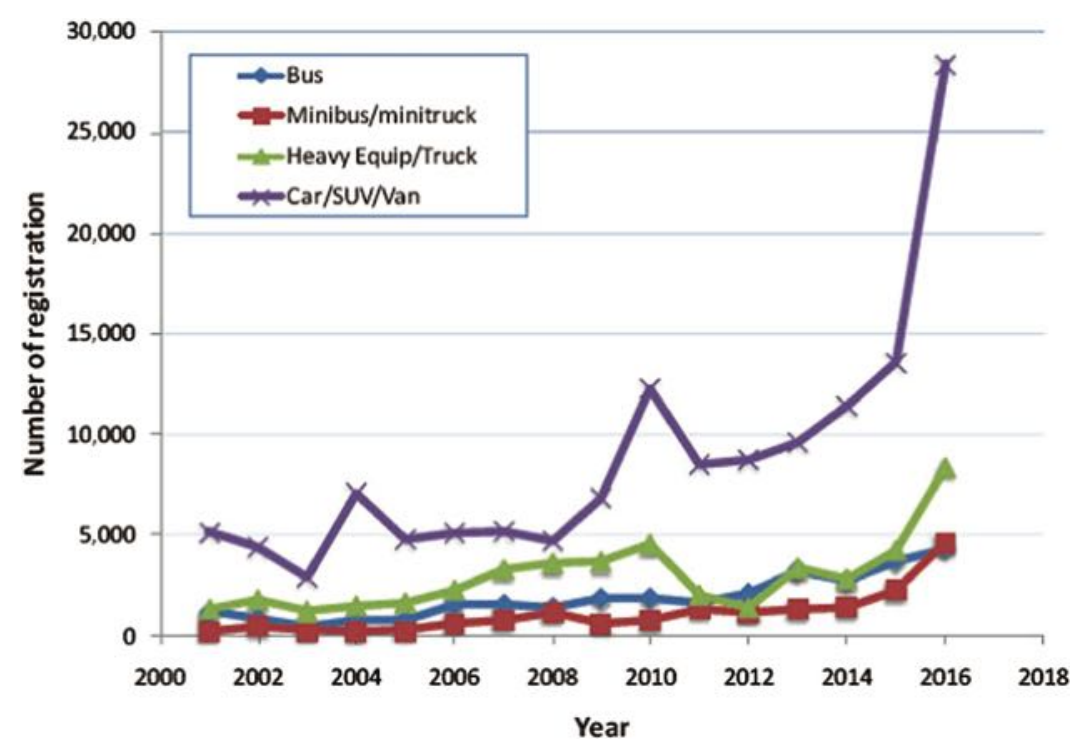

SUV = sport utility vehicle.

Source: Government of Nepal, Ministry of Population and Environment. 2016. Nationally Determined Contributions.

14. As part of Nepal's overarching framework for addressing climate change, Nepal's EnvironmentFriendly Vehicle and Transport Policy issue in 2014 sets the target of increasing the share of environment friendly vehicles, including electric vehicles, to a minimum of $20 \%$ of the total vehicle fleet by 2020 , encouraging manufacturing of electric vehicles, encouraging private sector to invest in electric vehicle parking stations and service centers, etc. (Global Green Growth Institute 2018). Objectives and targets relating to electric mobility are also set in the National Sustainable Transport Strategy for Nepal (2015-2040), formulated by the Ministry of Physical Infrastructure and Transport in collaboration with United Nations Centre for Regional Development (UNCRD) (Ministry of Physical Infrastructure and Transport 2015). Among others, they include promoting electric vehicles across all systems, introducing public electric bus transportation in urban areas, encouraging the development of a high-priority national 


\section{Figure 10: Carbon Dioxide Emissions from Various Land Transport Modes}

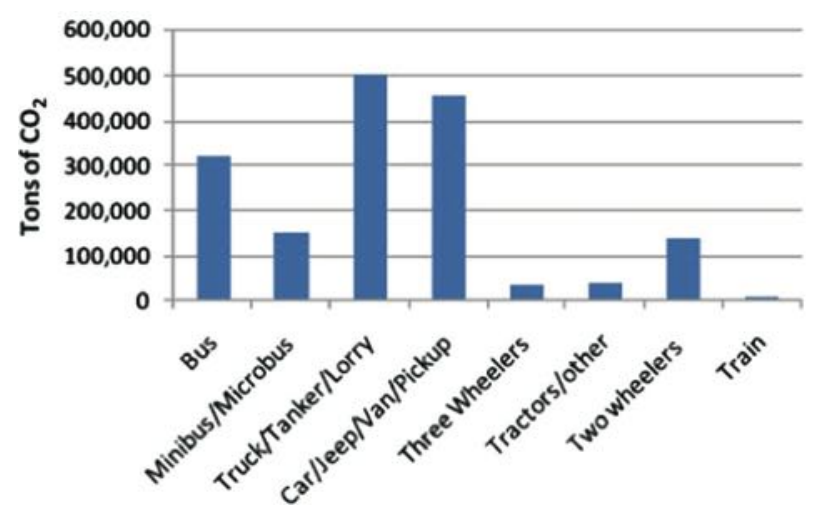

$\mathrm{CO}_{2}=$ carbon dioxide.

Source: Government of Nepal, Ministry of Population and Environment. 2017. Nepal's GHG Inventory-For Third National Communication to the UNFCCC. http://mofe.gov.np/noticefile/Nepal\%E2\%80\%99s\%20GHG\%2OInventory-Final_ version_1562308551.pdf.

electric rail system, and aligning and integrating the development of hydropower with the development of electric mobility (vehicles). The Nationally Determined Contribution (NDC) of Nepal reaffirms that by $2020 \mathrm{Nepal}$ aims to increase the share of electric vehicle up to 20\% from 2010 level. The NDC further sets out that by $2050 \mathrm{Nepal}$ will decrease its dependency on fossils in its transport sector by $50 \%$ through effective mass public transport means while promoting energy efficient and electric vehicles. It also aims to develop its electrical (hydropowered) rail network by 2040 to support mass transportation of goods and public commuting (Ministry of Population and Environment 2016). In the Electricity Demand Forecast Report (2015-2040), the policy intervention scenario makes the assumption that $18 \%$ of the total passenger kilometers $(\mathrm{km})$ demand will be fulfilled by electric car and $7 \%$ by electric metro in city by 2025 (Water and Energy Commission Secretariat 2017). Meanwhile, the Government of Nepal has created a fiscal environment in favor of electric vehicles. For example, electric vehicles for private transport are entitled to a reduced customs duty of $10 \%$ (as compared to a customs duty of $80 \%$ applied to fossil fuel vehicles for private usage) and the exemption of value-added tax (VAT) (as compared to a VAT of 13\% levied on fossil fuel vehicles for private usage) (Ministry of Finance 2016). All these policies and analyses have sent clear signals about the Government of Nepal's decision and plan to electrify and decarbonize its transport sector.

15. In addition to the benefit of carbon emissions reduction, electrifying Nepal's transport sector is also expected to generate the benefit of enhancing the energy security in Nepal. Using a bottom-up energy system model of Nepal, Shakya and Shrestha (2011) assessed the effects of meeting a part of land transport demand through electrifying vehicles in Nepal across various indicators of energy security. It was found that the electrification of Nepal's transport sector can improve the diversification of its primary energy supply, reduce the imported energy, and lower oil consumption per capita, thereby collectively contributing to enhancing the overall energy security of Nepal. Similar points were also made by the National Energy Strategy of Nepal, the modeling results of which suggested that promoting alternative energy for transport sector plays a crucial role in saving consumption of oil products and therefore easing the increasing import of oil products (Water and Energy Commission Secretariat 2013). This energy security perspective further justifies the significance of exploring feasible options to materialize the intended electrification of Nepal's transport sector. 


\section{HYDROGEN AS A POTENTIAL OPTION}

16. Against this background, while the Government of Nepal is making efforts to materialize its announced policies, strategies, and project development plans for its energy sector and major energy end-use sectors such as transport sector, it is advisable that alternative solutions are explored to supplement proven technologies and established practices, contributing to address the challenges facing the various sectors of Nepal. In particular, (i) the abundance of its hydropower resources, (ii) the seasonality of electricity generated by its run-of-the-river hydropower plants resulting in Nepal having surplus electricity during wet season and acute capacity shortage during dry season, and (iii) the uncertainties associated with materializing hydropower projects in its pipeline, as discussed above, in a combined way tend to point to the potential direction of storing the surplus electricity, which otherwise would have been curtailed, for electricity supply and shortage mitigation during dry season. In addition to meeting peak demand, stored electricity can also be utilized to power vehicles-contributing to achieving Nepal's announced objectives of electrifying and decarbonizing its transport sector. From this perspective, hydrogen offers a technological option that is potentially viable in Nepal's context.

17. Hydrogen is a molecular component abundant in nature. Odorless and nontoxic, hydrogen has the highest energy content of common fuels by weight, which is nearly three times that of gasoline (IEA 2017). Hydrogen is not found free in nature but can be produced from various primary energy sources (fossil fuels or biomass) or secondary energy sources (electricity), depending upon regional resource availability. The hydrogen produced can then be used as a fuel for a wide range of end-use conversion processes in multiple sectors of the economy, such as power, transport, industry, and buildings. For example, hydrogen produced from electricity can be converted back to electricity using a fuel cell-an electrochemical device operating continuously in the presence of hydrogen and oxygen in the ambient air. From this perspective, it is important to note that hydrogen, like electricity, is not an energy source, but an energy carrier with high flexibility and applicability. As it does not contain carbon itself, hydrogen can be a near-zero emission energy carrier. However, similar to electricity, hydrogen's lifecycle carbon footprint is determined by the upstream primary energy source and technological process used for producing it. Depending on production scenarios, "grey hydrogen" can be produced from fossil fuels (sometimes also termed "black hydrogen" or "brown hydrogen"), "blue hydrogen" from fossil fuels with carbon capture, utilization, and storage, and "green hydrogen" from renewables (IEA 2019d; International Renewable Energy Agency [IRENA] 2019a).

18. Hydrogen from renewable energy is technically feasible and is expected to quickly approach economic competitiveness. The growth of this hydrogen supply option is driven by (i) the decreasing costs of renewable power generation, (ii) increasing power system integration challenges caused by rising shares of variable renewable power supply, (iii) the increasing deployment and the associated reduction in hydrogen production costs due to economies of scale, and (iv) learning-by-doing effects. There are strategically significant synergies existing between hydrogen and renewable energy. Firstly, large-scale adoption of hydrogen can substantially boost the market growth of renewable power generation and broaden the reach of renewable solutions in different sectors, such as industry (IRENA 2019a). Secondly, electrolyzers, which produce hydrogen using water and electricity, can be operated to mitigate the impacts of intermittent renewable energy and therefore provide ancillary services to power systems (IEA 2015; Rocheleau and Ewan 2016; Alshehri et al. 2019). Depending upon specific types, hydrogen electrolyzers are characterized by their fast ramp-up and ramp-down capabilities which currently are on a timescale of minutes or even seconds and are expected to have further improvements (IRENA 2018, 2019a). Hence, an electrolyzer can serve as a variable controllable load to respond to the need for frequency regulation, thereby adding demand-side flexibility to power systems with high levels of variable renewable energy (National Renewable Energy Laboratory [NREL] 2016; Rocheleau and Ewan 2016; IRENA 2019b). Thirdly, hydrogen can play a key role for seasonal storage in power systems 
with a large share of variable renewable energy (IEA 2015; IRENA 2018). With the envisaged growth in renewables, producing hydrogen through electrolysis using renewable electricity in combination with various modes of storage of the produced hydrogen can create short-term, seasonal, or long-term reserve for re-electrification and/or end-uses in various sectors when needed (IEA 2017; Reuß et al. 2017). Such a "time shifting with hydrogen" helps to avoid curtailment of variable renewable electricity and enhance the security of energy supply (IEA 2017; IRENA 2019a, 2019c). Across these scenarios, the lowering costs of green hydrogen will facilitate materializing the synergies in practice and enable their implementation at scale, thereby having significant implications for both power sector and the major energy end-use sectors. Figure 11 provides an illustration of using renewable energy to produce hydrogen, which subsequently can be stored and used to generate electricity through fuel cell, as and when needed. This application can be termed as "power-to-power," or more precisely, "renewables-to-power."

19. For the transport sector on the demand-side of the energy system, hydrogen can play a strategically important role in electrifying and/or decarbonizing the sector. When powered by hydrogen produced from renewables, fuel cell electric vehicles (FCEVs) provide a low-carbon mobility option with driving performance comparable to conventional vehicles. In the medium to high duty cycle segments characterized by long range or high utilization rate, FCEVs have advantages as they can overcome some of current limitations of batteries, such as weight, driving range and refueling time. Hence FCEVs expand the market for electric mobility to vehicles including trucks, buses, taxis, forklifts, etc. From this perspective, FCEVs can be regarded as being complementary to battery electric vehicles (BEVs) in the broader context of energy transition (IRENA 2018). At present, FCEVs remain costly with limited availability (IEA 2019a). However, the total cost of driving (TCD, measured in $\$ / \mathrm{km}$ ) of FCEV is expected to drop quickly with rapid ramp-up of sales, resulting in cost parity with plug-in hybrid vehicles by 2030 and that with conventional

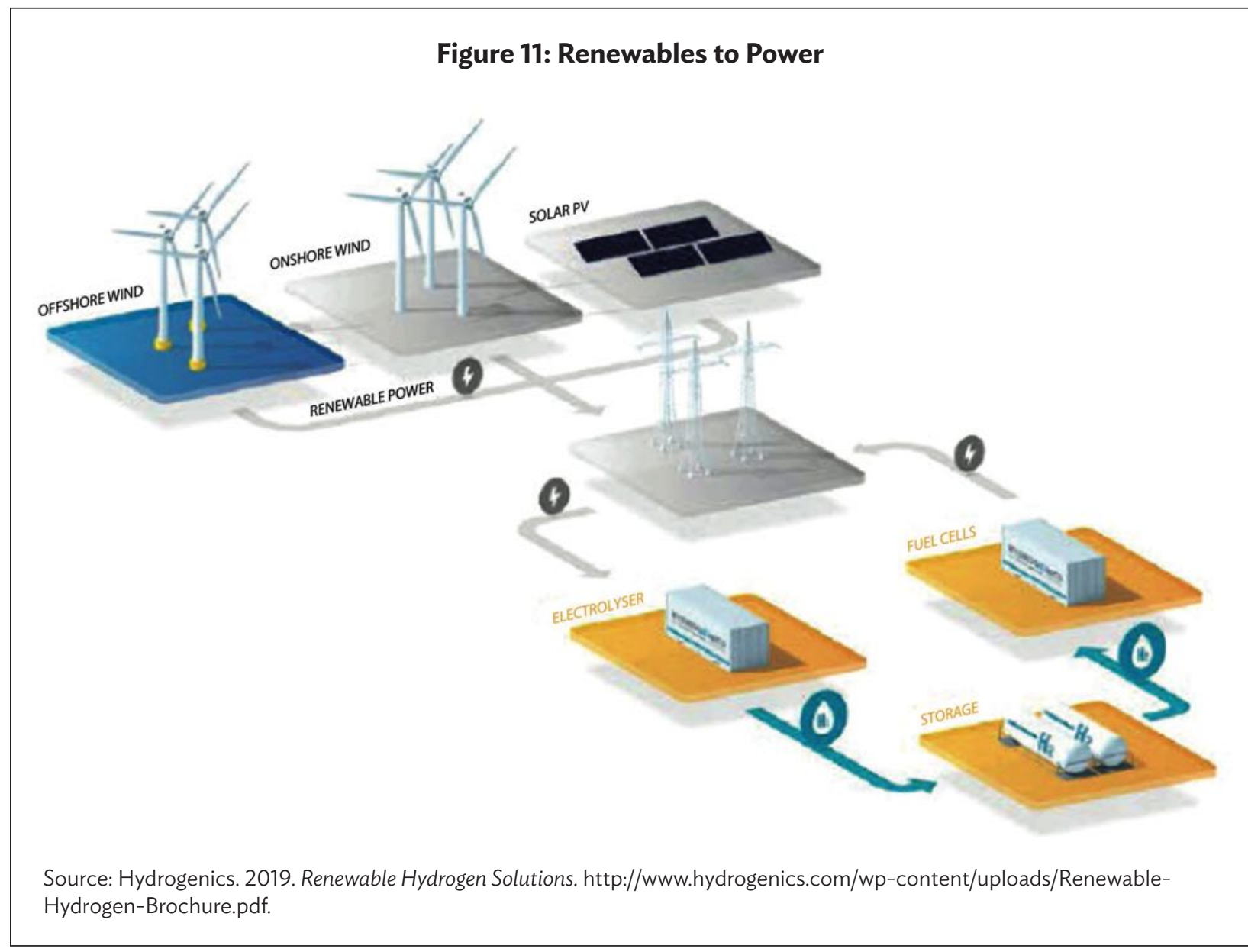




\section{Figure 12: Renewables to Mobility}

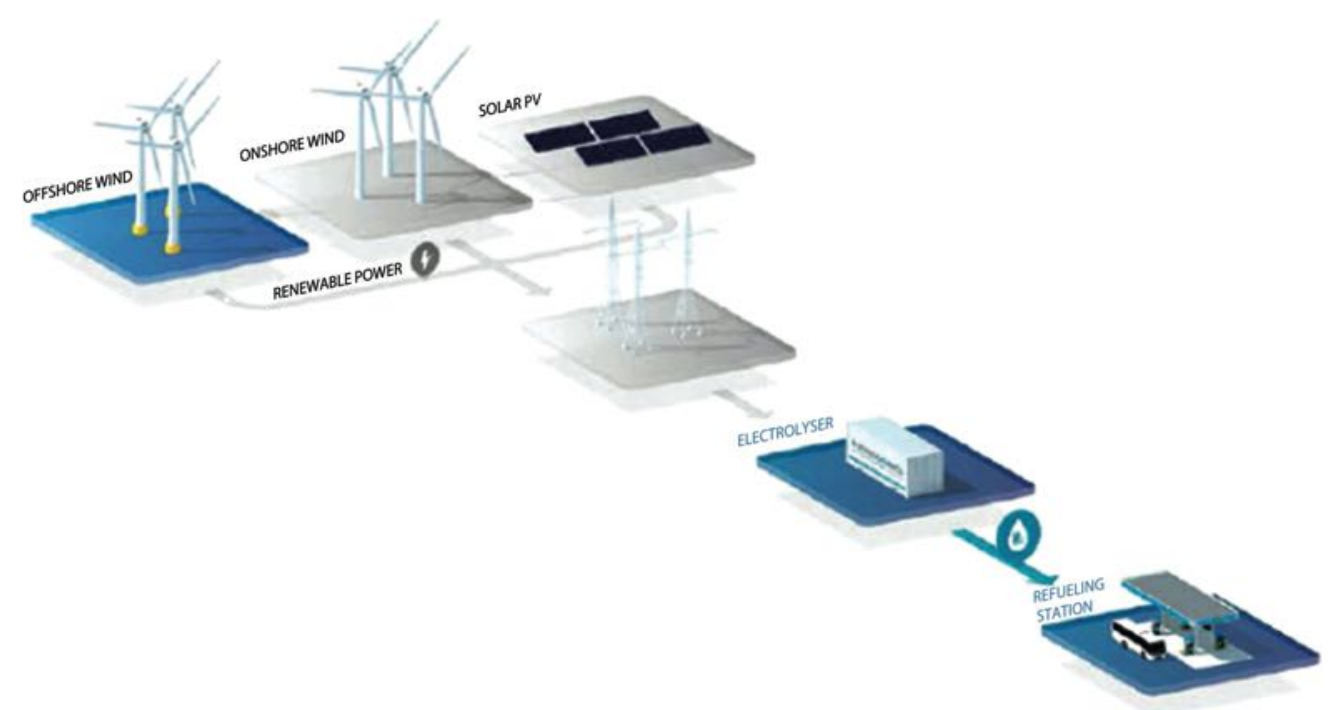

Source: Hydrogenics. 2019. Renewable Hydrogen Solutions. http://www.hydrogenics.com/wp-content/uploads/RenewableHydrogen-Brochure.pdf.

hybrid vehicles by 2040 (IEA 2015). Apart from road transport, there is also great potential for hydrogen to contribute to decarbonizing non-electrified trains, maritime transport and aviation, for which battery applications are challenging (IEA 2017; IRENA 2018). In addition, since FCEVs are emission-free at the tailpipe, using hydrogen in the transport sector has a positive impact on local air quality, regardless of whether the hydrogen is produced from renewable sources or fossil fuels (IEA 2017, 2019d). The use of green hydrogen to power vehicles can be described as "renewables to mobility," as illustrated in Figure 12.

\section{POSSIBLE HYDROGEN PRODUCTION IN NEPAL}

20. There are various established technology options for producing hydrogen. Currently, natural gas is the primary source of hydrogen production and the methods include steam methane reforming, partial oxidation, and autothermal reforming-all of which produce a synthesis gas mostly made of carbon monoxide and hydrogen. The synthesis gas produced is then converted to hydrogen and $\mathrm{CO}_{2}$. Coal or biomass can also produce hydrogen through gasification, a process which converts coal or biomass into a synthesis gas that is transformed into hydrogen and $\mathrm{CO}_{2}$. Hydrogen can also be produced through water electrolysis, an electrochemical process splitting water into hydrogen and oxygen (Figure 13). So far, electrolysis plays only a minor role in total hydrogen production worldwide-hydrogen production via water electrolysis accounts for around $4 \%$ to $5 \%$, mainly from chlorine production process where hydrogen is a by-product (IRENA 2018; IEA 2019d). Dedicated hydrogen production via water electrolysis is much less, accounting for around $0.1 \%$ of global total (IEA 2019d), due to cost and efficiency barriers as compared to other production methods (Goodall 2017; CarbonBrief 2019; DNV GL 2019; Shiva Kumar and Himabindu 2019). Given the abundant hydro resources and surplus electricity during wet season in Nepal, this report considers water electrolysis as a technologically appropriate method of producing hydrogen in Nepal. Further analyses and discussions on hydrogen prospects in the country are based on water electrolysis.

There are three main electrolyzer technologies-alkaline (ALK) electrolyzer, proton exchange membrane (PEM) electrolyzer, and solid oxide electrolysis cells (SOEC). Table 1 summarizes the techno-economic characteristics of these electrolyzer technologies. 


\section{Figure 13: Principles of Electrolysis}

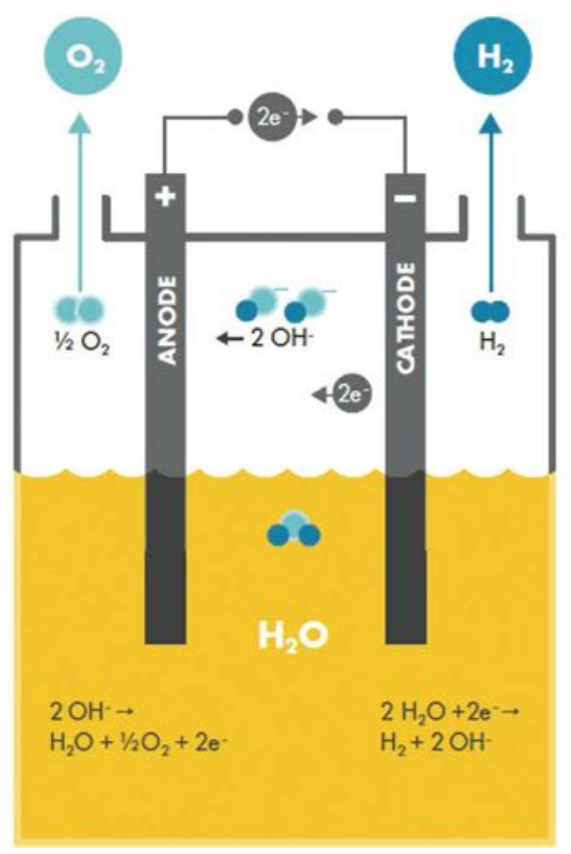

$\mathrm{H}_{2}$ = hydrogen, $\mathrm{H}_{2} \mathrm{O}$ = water, $\mathrm{O}_{2}$ = oxygen, $\mathrm{OH}$ = hydroxide.

Source: Shell. 2017. Shell Hydrogen Study: Energy of the Future? Sustainable Mobility through Fuel Cells and H2. https://www.shell. com/energy-and-innovation/new-energies/hydrogen/_jcr_content/par/keybenefits_150847174/link.stream/1496312627865/ 6a3564d61b9aff43e087972db5212be68d1fb2e8/shell-h2-study-new.pdf.

21. ALK technology is fully mature and commercial, having been used by industry for nearly 1 century for non-energy purposes, particularly in fertilizer and chlorine manufacturing. The operating range of ALK electrolyzers goes from a minimum load of $10 \%$ to full design capacity. ALK electrolysis is characterized by relatively low capital costs compared to other electrolyzer technologies due to the avoidance of precious materials (IEA 2019d). It is in the leading position of the electrolyzer market, accounting for most of the installed capacity worldwide (Shell 2017).

22 PEM electrolyzer is an emerging technology. It has started to be used commercially, mainly for small and medium applications (Shell 2017). PEM electrolyzers can overcome some of the operational drawbacks of ALK electrolyzers, such as the use of pure water to avoid the recovery and recycling of the potassium hydroxide electrolyte solution required by ALK electrolyzers, the relatively smaller size than ALK electrolyzers, ability to produce highly compressed hydrogen for decentralized production and storage at refueling station, wider operating range (0 to 160\% of design capacity), etc. (NREL 2016; IRENA 2018; IEA 2019d). The disadvantages of PEM electrolyzers are higher costs and shorter lifetime (IEA 2019d).

23. Compared to ALK and PEM, SOEC is the least mature technology as it is not yet commercialized and remains at demonstration stage (Shell 2017; IEA 2019d). Although currently with higher capital expenditure (CAPEX), SOEC requires lower material costs than ALK and PEM mainly due to the use of ceramics as electrolyte. While SOEC operates with high electrical efficiency, its requirement for high-temperature heat source may limit its long-term economic competitiveness (IRENA 2018). An operational advantage of SOEC over ALK and PEM is the possibility of operating an SOEC electrolyzer in reverse mode as a fuel cell, whereby hydrogen can be converted back to electricity. This means an SOEC electrolyzer could provide balancing services to the grid in combination with hydrogen storage facilities. Therefore, the overall utilization rate could be increased (IEA 2019d). 
Table 1: Techno-Economic Characteristics of Alkaline, Proton Exchange Membrane,
and Solid Oxide Electrolysis Cells

\begin{tabular}{|c|c|c|c|c|c|c|c|c|c|}
\hline & \multicolumn{3}{|c|}{ ALK } & \multicolumn{3}{|c|}{ PEM } & \multicolumn{3}{|c|}{ SOEC } \\
\hline & 2019 & 2030 & Long-Term & 2019 & 2030 & $\begin{array}{l}\text { Long- } \\
\text { Term }\end{array}$ & 2019 & 2030 & $\begin{array}{l}\text { Long- } \\
\text { Term }\end{array}$ \\
\hline $\begin{array}{l}\text { Electrical } \\
\text { efficiency } \\
(\%, \text { LHV) }\end{array}$ & $63-70$ & $65-71$ & $70-80$ & $56-60$ & $63-68$ & $67-74$ & $74-81$ & $77-84$ & $77-90$ \\
\hline $\begin{array}{l}\text { Operating } \\
\text { pressure } \\
\text { (bar) }\end{array}$ & $1-30$ & & & $30-80$ & & & 1 & & \\
\hline $\begin{array}{l}\text { Operating } \\
\text { temperature } \\
\left({ }^{\circ} \mathrm{C}\right)\end{array}$ & $60-80$ & & & $50-80$ & & & $\begin{array}{l}650- \\
1,000\end{array}$ & & \\
\hline $\begin{array}{l}\text { Stack } \\
\text { lifetime } \\
\text { (operating } \\
\text { hours) }\end{array}$ & $\begin{array}{l}60,000- \\
90,000\end{array}$ & $\begin{array}{l}90,000- \\
100,000\end{array}$ & $\begin{array}{l}100,000- \\
1,500,000\end{array}$ & $\begin{array}{c}30,000- \\
90,000\end{array}$ & $\begin{array}{l}60,000- \\
90,000\end{array}$ & $\begin{array}{l}100,000- \\
1,500,000\end{array}$ & $\begin{array}{c}10,000- \\
30,000\end{array}$ & $\begin{array}{c}40,000- \\
60,000\end{array}$ & $\begin{array}{c}75,000- \\
10,000\end{array}$ \\
\hline $\begin{array}{l}\text { Load range } \\
\text { (\%, relative } \\
\text { to nominal } \\
\text { load) }\end{array}$ & $10-110$ & & & $0-160$ & & & $20-100$ & & \\
\hline $\begin{array}{l}\text { CAPEX } \\
(\$ / k W)\end{array}$ & $\begin{array}{l}500- \\
1,400\end{array}$ & $400-850$ & $200-700$ & $\begin{array}{l}1,100- \\
1,800\end{array}$ & $\begin{array}{l}650- \\
1,500\end{array}$ & $200-900$ & $\begin{array}{c}2,800- \\
5,600\end{array}$ & $\begin{array}{l}800- \\
2,800\end{array}$ & $\begin{array}{l}500- \\
1,000\end{array}$ \\
\hline
\end{tabular}

$\$=$ United States dollar, $\mathrm{ALK}=$ alkaline, $\mathrm{CAPEX}=$ capital expenditure, $\mathrm{kW}=$ kilowatt, $\mathrm{LHV}=$ lower heating value, $\mathrm{PEM}=$ proton exchange membrane, SOEC = solid oxide electrolysis cell.

Sources: IEA. 2015. Technology Roadmap: Hydrogen and Fuel Cells. doi: 10.1007/SpringerReference_7300;

IEA. 2019d. The Future of Hydrogen: Seizing Today's Opportunities. https://www.iea.org/reports/the-future-of-hydrogen; and IRENA.

2018. Hydrogen from Renewable Power: Technology Outlook for the Energy Transition. https://www.irena.org/-/media/Files/IRENA/

Agency/Publication/2018/Sep/IRENA_Hydrogen_from_renewable_power_2018.pdf.

\section{POTENTIAL HYDROGEN VALUE CHAIN IN NEPAL}

24. In general, hydrogen value chain can follow many different paths. Hydrogen can be produced from a wide variety of sources and used in a wide variety of applications, with value chains containing different combinations of supply, handling and demand technologies. In the specific context of Nepal as described above, the possible hydrogen value chain that would potentially make technological and economic sense should be based on hydrogen production from surplus hydropower that otherwise would have been curtailed during wet season and using the stored hydrogen to generate power to meet demand during dry season ("hydropower-to-power"), to power FCEVs ("hydropower-to-mobility"), or a combination of both applications. A Nepal-specific hydrogen value chain is highlighted using green frames on the general value chain in Figure 14. 


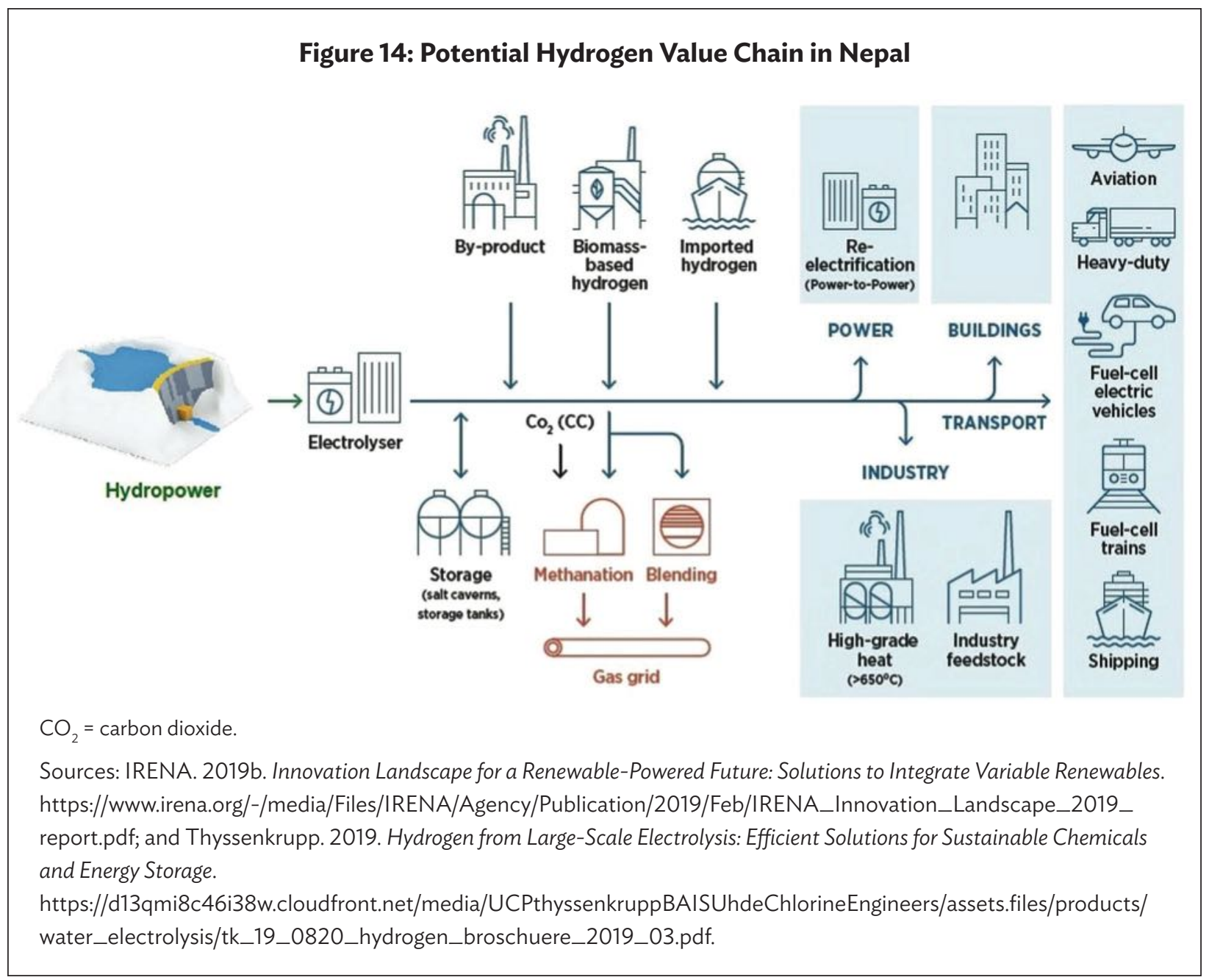

\section{COST ANALYSIS OF HYDROGEN VALUE CHAIN}

\section{A. Production Cost}

25. The production costs of hydrogen from water electrolysis, measured through levelized cost of hydrogen production ( $\mathrm{LCOH}$ ), are a function of various technical and economic factors, with CAPEX requirements, conversion efficiency, electricity costs and annual operating hours being the most important ones.

26. CAPEX is a critical determinant of the cost of hydrogen production. Presently, CAPEX requirements for ALK electrolyzers are in the range of $\$ 500-\$ 1,400 /$ kilowatt-electric ( $\mathrm{kWe}$ ) and $\$ 1,100$ $\$ 1,800 / \mathrm{kWe}$ for PEM electrolyzers (Table 1). ALK electrolyzers are cheaper than PEM electrolyzers owing to past development and established production volumes. However, PEM electrolyzers have been experiencing CAPEX reduction in recent years and are expected to have their CAPEX in the range of $\$ 650-\$ 1,500 / \mathrm{kWe}$ by 2030 , with considerable overlap with the expected 2030 CAPEX range of ALK (\$400-\$850/kWe). While currently being more expensive, SOEC is expected to see its CAPEX decrease significantly and get closer to that of PEM electrolyzers over the long-term (Table 1). Out of 
the CAPEX of ALK and PEM electrolyzers, the electrolyzer stack accounts for a substantial share. The rest are attributable mainly to power electronics, gas-conditioning, and plant components (IEA 2019d). The predicted future cost reductions are influenced by technological advances and economies of scale in the manufacturing processes (e.g., less costly materials for electrodes and membranes, development of larger size electrolyzers, etc.) Figure 15 gives a perspective for CAPEX reduction upon the use of multistack systems both for PEM and ALK electrolyzers. It shows that the extent to which CAPEX can be reduced by using multistack systems is much greater for PEM than for ALK electrolyzers (Proost 2019).

27. The load factor of electrolyzers has a strong impact on $\mathrm{LCOH}$. With the increase of operating hours, the impact of CAPEX on the LCOH declines because the amortization of CAPEX is allocated to larger quantity of hydrogen production. In general, to produce hydrogen from renewable electricity, the load factor of electrolyzers should exceed $50 \%$, given the current prevailing CAPEX levels. However, a load factor of about 35\% is the threshold above which nearly optimal LCOH start to be approached (IRENA 2019a). Meanwhile, when the load factor increases, the electricity costs start to have gradually stronger impact on the $\mathrm{LCOH}$. Figure 16 shows that for a given electricity price, the increase of load factor helps bring down the LCOH, for all levels of CAPEX. The higher the load factor, the less the impact of CAPEX on LCOH. Meanwhile, for a given CAPEX and a given load factor, the more expensive the electricity, the higher the $\mathrm{LCOH}$. The increase of load factor does not contribute to decreasing the differences between LCOHs under different electricity prices.

Figure 15: Capital Expenditure Reduction Upon Use of Multistack Systems
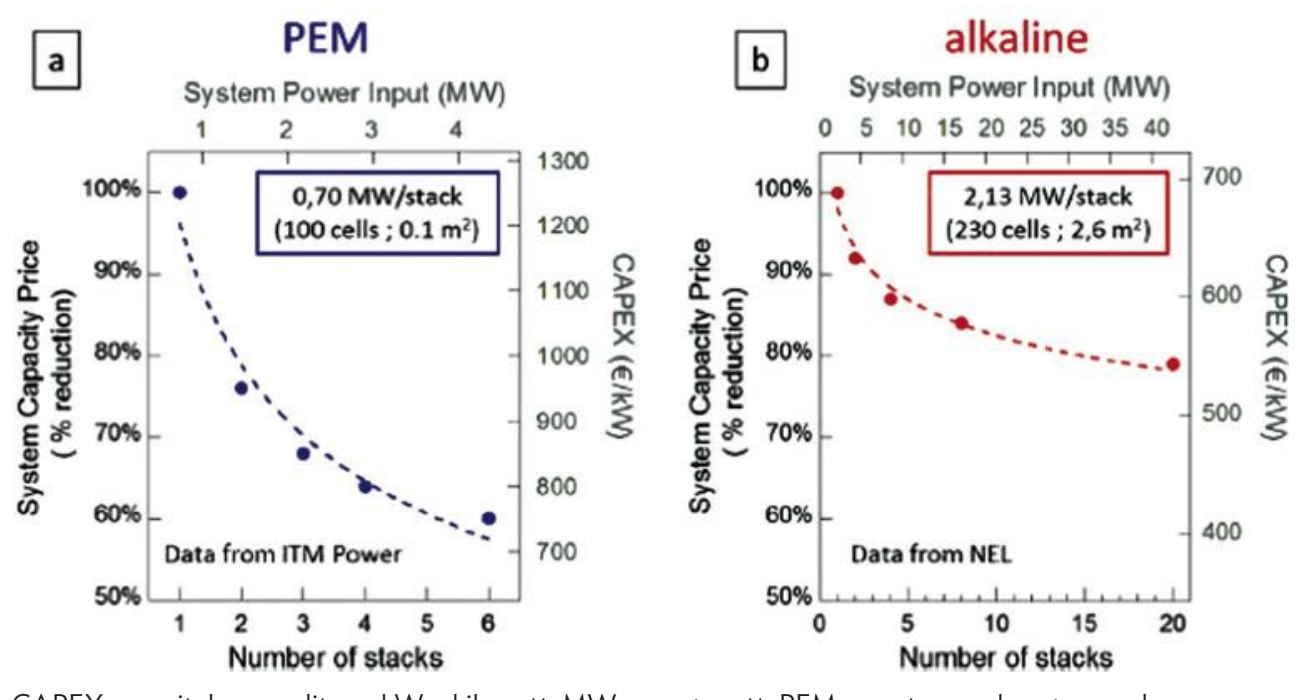

$€=$ euros, CAPEX = capital expenditure, $\mathrm{kW}=$ kilowatt, $\mathrm{MW}=$ megawatt, $\mathrm{PEM}=$ proton exchange membrane.

Source: J. Proost. 2019. State-of-the Art CAPEX Data for Water Electrolysers, and their Impact on Renewable Hydrogen Price Settings. International Journal of Hydrogen Energy. 44(9). pp. 4406-4413. doi: 10.1016/j.ijhydene.2018.07.164. 


\section{Figure 16: The Impact of Load Factor and Electricity Price on Levelized Cost of Hydrogen Production}
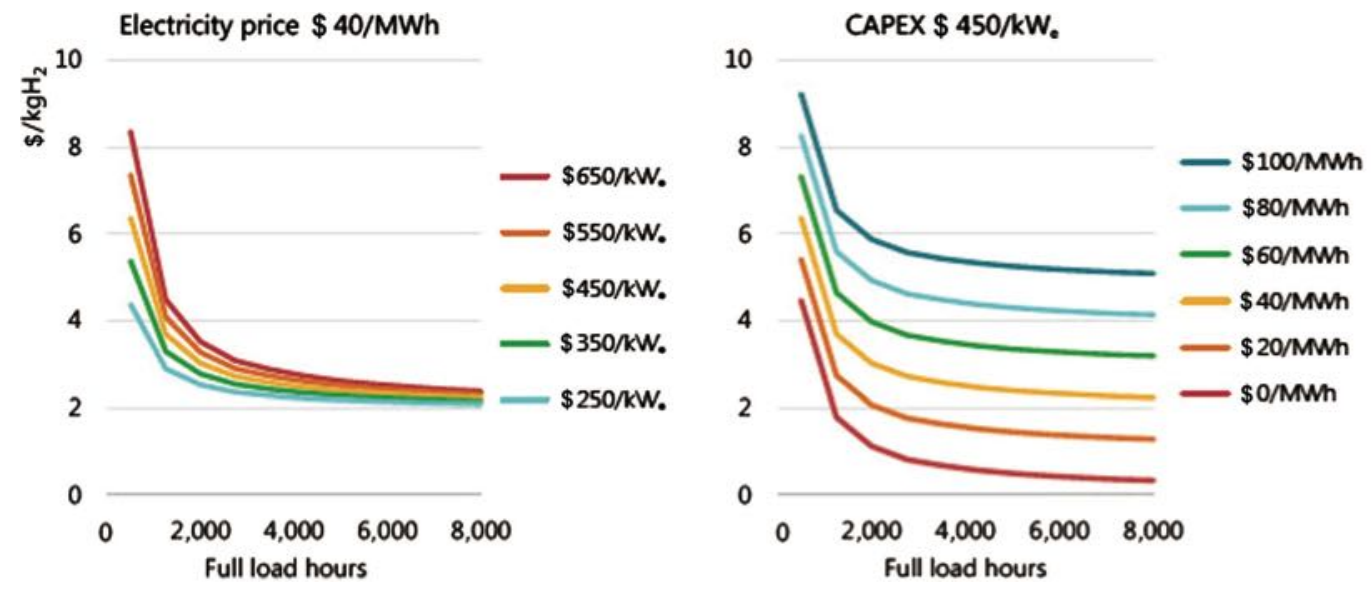

CAPEX = capital expenditure, $\mathrm{kgH}_{2}=$ kilogram of hydrogen, $\mathrm{kW}=$ kilowatt, $\mathrm{LHV}=$ lower heating value, $\mathrm{MWh}=$ megawatt-hour. Notes: Based on an electrolyser efficiency of $69 \%$ (LHV) and a discount rate of $8 \%$.

Source: IEA. 2019d. The Future of Hydrogen: Seizing Today's Opportunities.

https://www.iea.org/reports/the-future-of-hydrogen.

28. The combined impact of electrolyzer load factor and electricity cost on LCOH is dynamic, as shown in Figure 17. At low load factors, low-cost electricity is usually available for limited hours within a year. The low utilization of electrolyzer means that the CAPEX needs to be amortized over a small volume of hydrogen produced, therefore leading to high $\mathrm{LCOH}$. An increase of the load factor increases the cost

Figure 17: Dynamic Impact of Electrolyzer Load Factor and Electricity Cost on Levelized Cost of Hydrogen Production

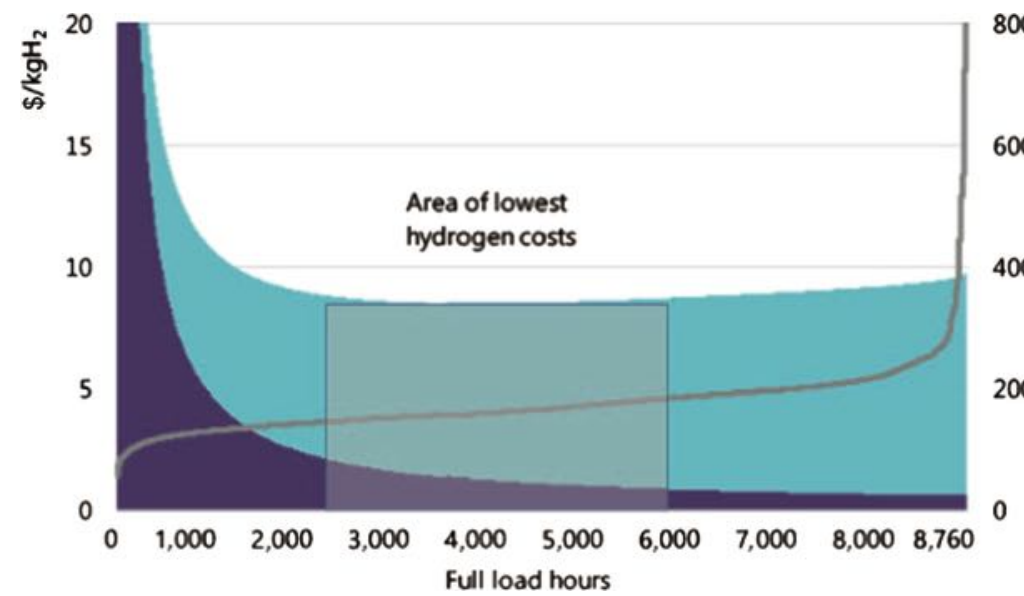

600

$400 \quad$ Electricity use

200

CAPEX+OPEX

Electricity price

(right axis)

CAPEX = capital expenditure, $\mathrm{kgH}_{2}=$ kilogram of hydrogen, $\mathrm{LHV}=$ lower heating value, $\mathrm{MWh}$ = megawatt-hour, OPEX = operating expenses.

Note: CAPEX $=\$ 800 / \mathrm{kW}_{0}$; efficiency LHV $=64 \%$; discount rate $8 \%$.

Source: IEA. 2019d. The Future of Hydrogen: Seizing Today's Opportunities.

https://www.iea.org/reports/the-future-of-hydrogen. 
of electricity, but at the same time, the increased utilization of the electrolyzer tends to reduce the cost of unit production of hydrogen. The two effects offset each other, and in a combined way lead to a nearly flat $\mathrm{LCOH}$ at the load factor range of $40 \%$ to $80 \%$. With further increase of the load factor, the effect of higher electricity cost during peak hours prevails, leading to higher LCOH (IRENA 2018; IEA 2019d).

29. An alternative to using grid electricity for hydrogen production is off-grid dedicated electricity generation from renewables. Strategically installing electrolyzers at locations with abundant renewable resources can be a potential low-cost hydrogen supply option. This may still be the case even after taking into consideration the costs associated with hydrogen transmission and distribution to end users (IEA 2019d).

30. In situations where surplus renewable electricity with near-zero cost (that otherwise would be curtailed) is used to produce hydrogen - such as the hypothetical scenario in Nepal - the effect of CAPEX and operating expenses (OPEX) of electrolyzers in the LCOH is substantially dominant at low- to midrange load factors. Based on an estimated electricity price duration curve for year 2050 characterized by zero-cost surplus electricity for approximately 3,000 hours per year, a study by DNV GL (2019) argues that hydrogen production using surplus electricity can be a viable option if the operating hours are above 2,100 when its $\mathrm{LCOH}$ is comparable with that of the current state-of-the-art reference method, steam

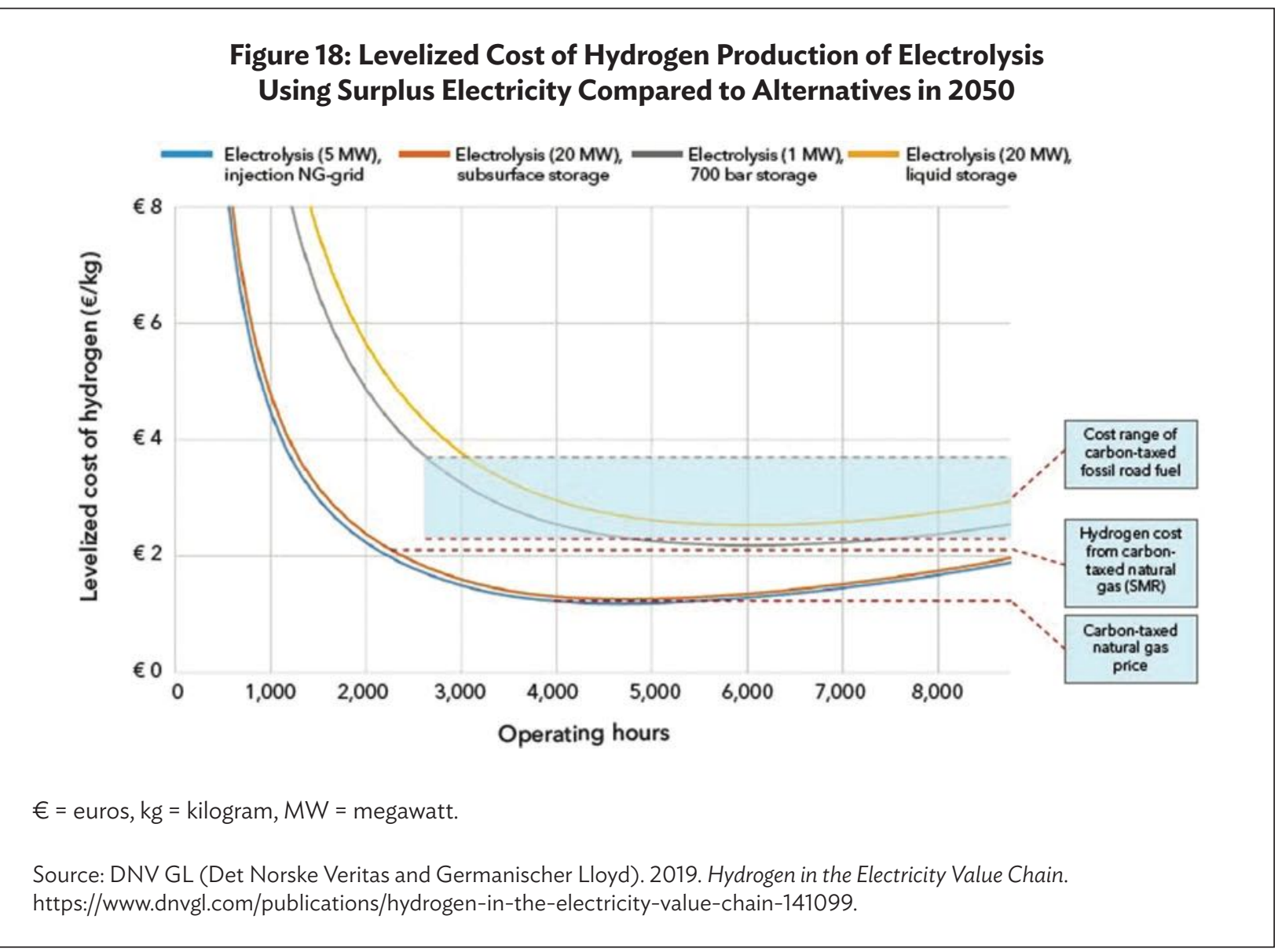


methane reforming (Figure 18). This is considered highly relevant to Nepal where substantial amount of surplus electricity would be available during its wet season. In addition, Figure 18 shows the impacts of the economy of scale (small-scale local production versus large-scale centralized production) on the $\mathrm{LCOH}$ and the additional costs incurred by storage requirements such as pressurization and liquefaction are all important factors to be evaluated.

\section{B. Storage and Transportation Costs}

31. The costs associated with hydrogen storage and transportation can make a difference to the economic competitiveness of hydrogen. The choices of hydrogen delivery infrastructure and the associated costs are therefore strategically important to the prospect of hydrogen production and utilization in Nepal.

32. In general, the most appropriate storage medium for hydrogen depends upon the volume and duration of storage, the required speed of discharge, and the geographic availability of different options. For the "hydropower-to-mobility" value chain in Nepal, it is straightforward to consider the option of storing hydrogen as a gas in pressurized containers, which currently is the most commonly used storage option for small-scale mobile and stationary applications. As a well-established technology, containers storing compressed hydrogen have high discharge rates and efficiencies of around 99\%, making them appropriate for short-term smaller-scale applications where a local stock needs to be readily available, such as refueling stations (IEA 2019d). Currently the levelized cost of storage by pressurized containers ranges from $\$ 0.09-\$ 1.19 /$ kilogram of hydrogen $\left(\mathrm{kgH}_{2}\right)$, depending upon pressure, operating lifetime and cycles (BloombergNEF 2019). For the "hydropower-to-power" value chain in Nepal, it would require much longer-term and larger volume storage as the hydrogen produced from hydropower will be used to bridge major seasonal variations in electricity supply and/or to provide power system resilience.

33. To meet the requirement of long-term and large volume storage, the subsurface storage of compressed gaseous hydrogen is generally the best option, with the specific options being salt caverns, aquifers, and depleted gas/oil reservoirs (DNV GL 2019; IEA 2019d). However, these are not expected to be relevant to Nepal due to the constraint of geological availability. When geological storage is not possible, chemical storage through converting hydrogen to ammonia tends to be the most cost competitive alternative for long-term and large volume storage, due primarily to its relatively low CAPEX

\section{Figure 19: Levelized Cost of Hydrogen Storage and Typical Storage Duration, 2019}

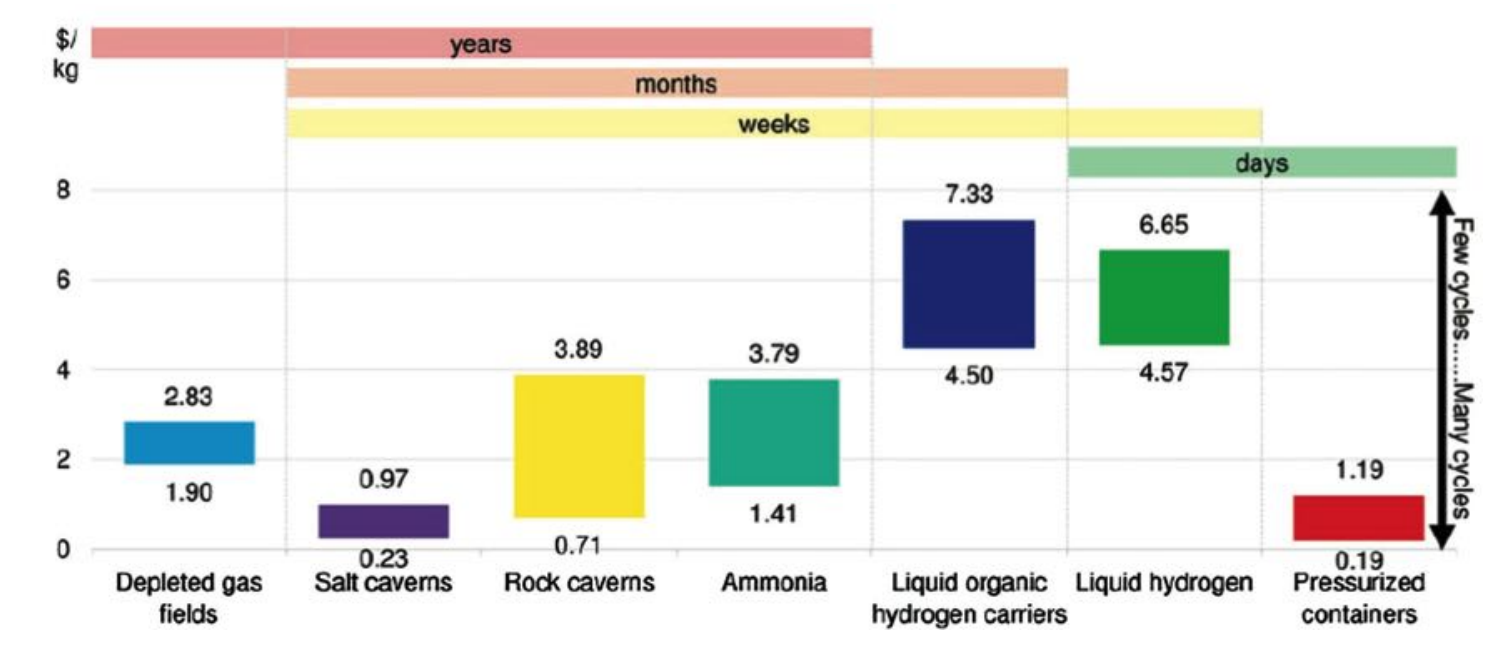

Source: BloombergNEF. 2019. Hydrogen: The Economics of Storage-Storing Clean Molecules at Scale. 
at low cycling rates (BloombergNEF 2019). The synthesis of ammonia based on water electrolysis is already an established process (Andersson and Grönkvist 2019). Figure 19 shows that the current levelized cost of using ammonia to store hydrogen is in the range of $\$ 1.41-\$ 3.79 / \mathrm{kgH}_{2}$, depending on the number of cycles and whether the expense of reconversion of ammonia back to hydrogen can be spared by using ammonia directly (e.g., in fuel cells). The cost could fall by $38 \%$ if more efficient ways of synthesizing ammonia are developed.

34. The options for transportation of hydrogen shall be aligned with options for hydrogen storage. For transmission of compressed hydrogen, the option of using existing natural gas grids in which hydrogen can be blended into natural gas stream is not relevant to Nepal, because the country has no natural gas infrastructure and natural gas is not part of Nepal's energy mix (ADB 2017). A viable alternative is to develop new dedicated hydrogen transmission pipeline. The cost of transporting compressed hydrogen for $1,500 \mathrm{~km}$ would be around $\$ 1 / \mathrm{H}_{2}$, taking into account all capital and operating costs (Figure 20). For ammonia, it is often transported by pipeline, and new pipelines for ammonia would be cheaper than new pipelines for pure hydrogen (IEA 2019d). Although pipeline transmission of ammonia appears to be cheaper than compressed hydrogen (Figure 20), the cost required by ammonia conversion will increase the cost of ammonia transmission by about $\$ 1.50 / \mathrm{H}_{2}$.

35. Local distribution delivers the transmitted hydrogen to final users. Similar to transmission, distribution volume, distance and end-user needs are major factors for evaluating distribution options relevant to Nepal's context. For compressed hydrogen, the possible options would include trailer trucks for short distances, which are a relatively costly option, and dedicated hydrogen distribution pipelines for large volume distribution over longer distances, which become increasingly cost-competitive. For ammonia, it can be distributed by road tanker. Distribution by pipeline may also be an option provided that there is large demand for ammonia. Figure 21 compares the cost of various options of hydrogen distribution to a centralized facility. Note that the line for ammonia does not include reconversion cost which is about $\$ 1 / \mathrm{kgH}_{2}$.

\section{Figure 20: Cost of Hydrogen Transmission by Pipeline}

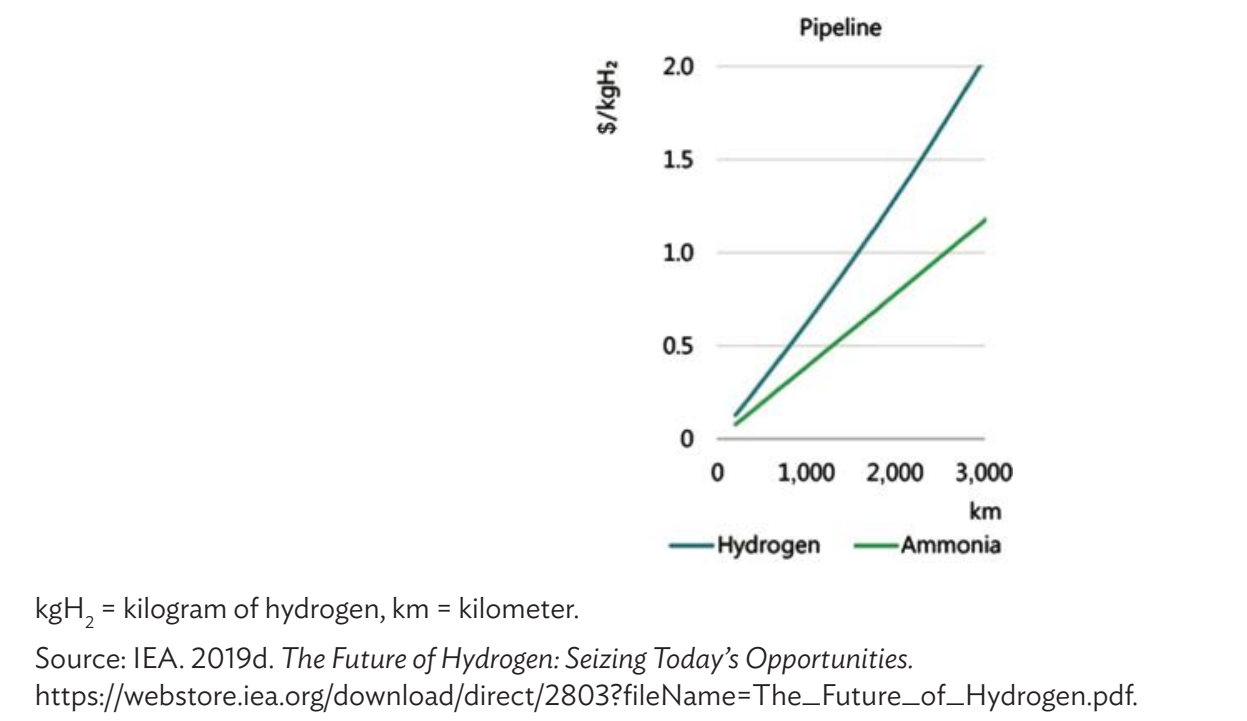


Figure 21: Cost of Hydrogen Distribution by Various Means

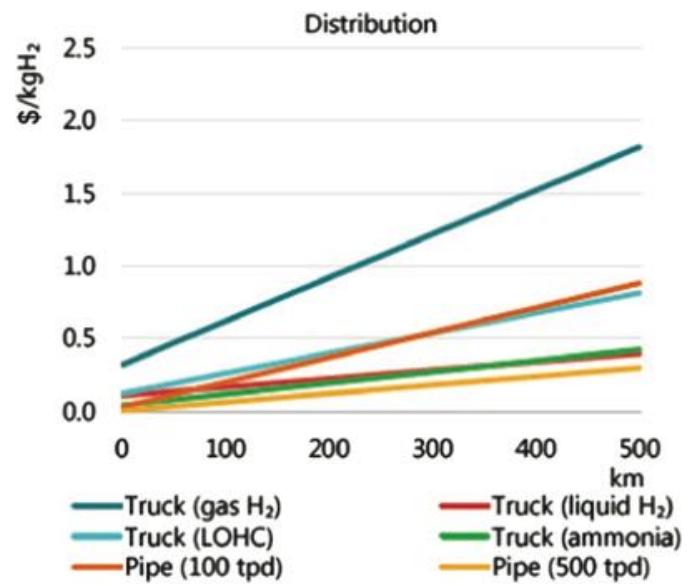

$\mathrm{kgH}_{2}=$ kilogram of hydrogen, $\mathrm{LOHC}=$ liquid organic hydrogen carriers, tpd = tonnes per day.

Source: IEA. 2019d. The Future of Hydrogen: Seizing Today's Opportunities.

https://www.iea.org/reports/the-future-of-hydrogen.

\section{Cost of Hydrogen for Electricity Generation and Storage}

36. For the "hydropower-to-power" value chain, hydrogen and ammonia can be used as fuels in gas turbines, combined-cycle gas turbines (CCGTs), or fuel cells to generate electricity and provide lowcarbon flexibility to electricity systems with increasing shares of variable renewables. Figure 22 compares the levelized costs of electricity generation for load balancing by hydrogen-based power plants and the alternative option of natural gas power plants. As shown, the competitiveness of hydrogen-based plants

\section{Figure 22: Levelized Costs of Electricity Generation by Hydrogen-Based Technologies}

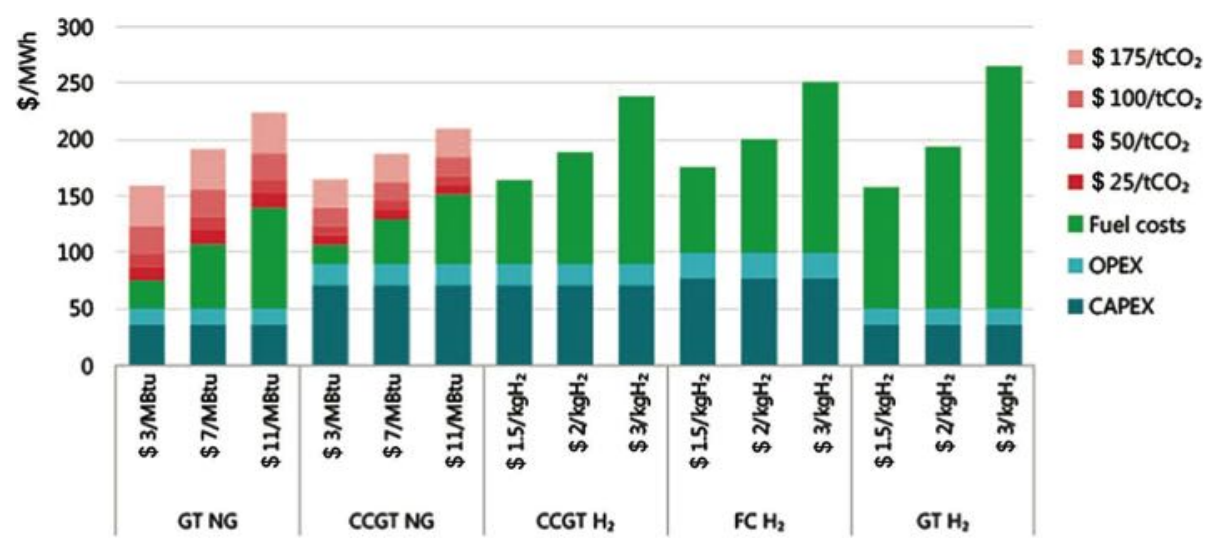

CAPEX = capital expenditure, $C C G T=$ combined-cycle gas turbine, $C C S=$ carbon capture and storage, $F C=$ fuel cell, GT = gas turbine, $\mathrm{H}_{2}$ = hydrogen, $\mathrm{kgH}_{2}=$ kilogram of hydrogen, $\mathrm{kW}=$ kilowatt, $\mathrm{MBtu}=$ million British thermal units, $\mathrm{MWh}=$ megawatt, $\mathrm{NG}=$ natural gas, $\mathrm{OPEX}=$ operating expenses, $\mathrm{tCO}_{2}=$ tonne of carbon dioxide.

Notes: CAPEX $=\$ 500 / \mathrm{kW}$ GT, $\$ 1,000 / \mathrm{kW}$ CCGT without CCS and hydrogen-fired CCGT, $\$ 1,000 / \mathrm{kW}$ FC. Gross efficiencies $(\mathrm{LHV})=42 \% \mathrm{GT}, 61 \%$ CCGT without CCS and hydrogen-fired CCGT, 55\% FC Economic lifetime $=25$ years for GT and CCGT, 20 years for FC Capacity factor 15\%. More information on the assumptions is available at www.iea.org/hydrogen2019.

Source: IEA. 2019d. The Future of Hydrogen: Seizing Today's Opportunities. https://www.iea.org/reports/the-future-of-hydrogen. 


\section{Figure 23: The Impacts of Discharge Duration and Electricity Input Cost on Levelized Costs of Electricity Storage}

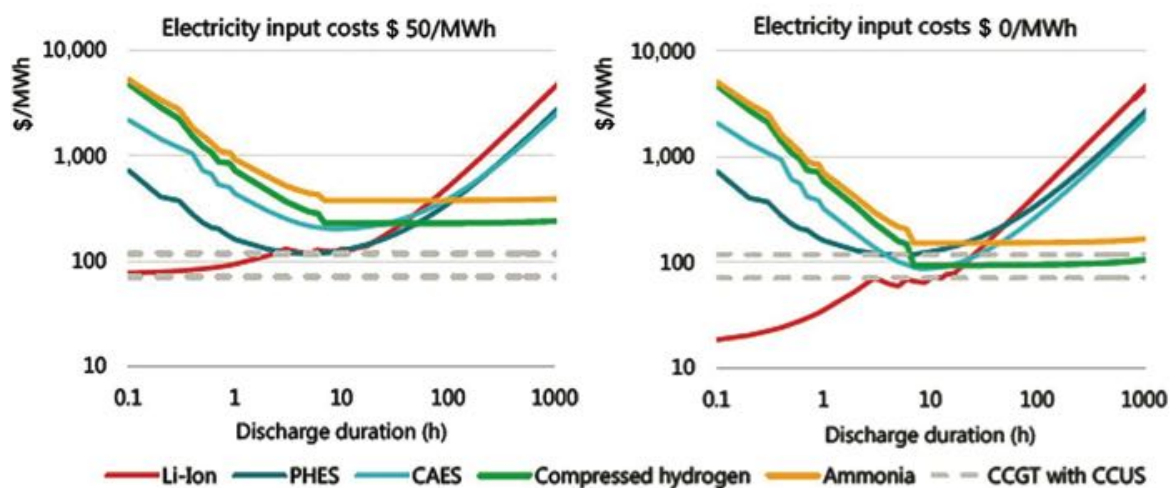

CAES = compressed air energy storage; CCGT = combined-cycle gas turbine; CCUS = carbon capture, utilization. and storage; $\mathrm{Li}$-Ion = litium-iion battery; MWh = megawatt; $\mathrm{PHES}=$ pumped-hydro energy storage.

Note: Compressed hydrogen storage refers to compressed gaseous storage in salt caverns ammonia storage in tanks.

Source: IEA. 2019d. The Future of Hydrogen: Seizing Today's Opportunities.

https://www.iea.org/reports/the-future-of-hydrogen.

with natural gas plants depends upon natural gas price, hydrogen price and potential carbon prices. The sum of CAPEX and OPEX components in the total levelized costs are about $\$ 80 /$ megawatt-hour (MWh) and $\$ 100 / M W h$ for hydrogen CCGT and hydrogen fuel cell, respectively. Based on the assumption that producing $20 \mathrm{kWh}$ electricity requires $1 \mathrm{~kg}$ hydrogen, ${ }^{2}$ the costs of electricity generation using hydrogen based CCGT and hydrogen fuel cell are $\$ 1.60 / \mathrm{kgH}_{2}$ and $\$ 2.00 / \mathrm{kgH}_{2}$, respectively.

37. There are various potential options that can serve the purpose of long-term and large-scale energy storage to balance seasonal variations in renewable power generation. Storing electricity in the form of ammonia appears to be a potentially viable option for Nepal in the absence of suitable geological conditions for underground storage of compressed hydrogen. Compared with other options such as pumped storage or battery storage, hydrogen storage through ammonia, owing to it relatively low CAPEX, is more expensive for discharge durations as short as a few hours but becomes competitive when discharge durations increase (Figure 23). With discharge durations increasing to about 100 hours, ammonia emerges as the second most economic storage option among the different technologies. This tipping point may be reached at discharge durations of about 60-70 hours, if the electricity cost decreases from $\$ 50$ to $\$ 0 / \mathrm{MWh}$.

\section{POTENTIALS OF “HYDROPOWER-TO-X” IN NEPAL}

38. Considering that (i) hydrogen production and utilization in the context of energy system is an emerging technological option worldwide; (ii) Nepal does not have existing policies or strategies directly

2 According to IEA (IEA 2019d, p. 157), if 1\% of the globally installed gas-fired power capacity (or 25 GW) was fired by hydrogen (or ammonia) in 2030, this would result in annual electricity generation of around 90 terawatt-hours (TWh) (40\% load factor) and hydrogen demand of $4.5 \mathrm{MtH}_{2}$. In addition, fuel cells have electric efficiencies (50\%-60\%) similar to those of CCGTs (IEA 2019d, p. 156). Based on these considerations, it can be calculated that $1 \mathrm{kgH}_{2}$ can produce $20 \mathrm{kWh}$ electricity given existing technologies. 
relating to hydrogen; and (iii) the status quo of Nepal's energy sector development, the weakness of relevant institutional policy and regulatory framework and inadequacy of financing, this study chooses year 2025 as the target year from which the hypothetical scenario where surplus hydropower during wet season is utilized to produce hydrogen is likely to be realized.

39. The total installed capacity of hydropower in Nepal by end of FY2019 was 1,113.48 MW, including both NEA-owned and IPPs-owned plants. The total electricity generated during this period was 4,738.16 GWh (NEA 2019). This suggests a capacity factor of approximately $48 \%$. To estimate the total hydropower installed capacity by 2025 , it is necessary to refer to the White Paper issued by the Government of Nepal in 2018 (Ministry of Energy Water Resources and Irrigation 2018). While the White Paper has set the plan of having total installed capacity reach $3 \mathrm{GW}$ in 3 years, $5 \mathrm{GW}$ in 5 years, and $15 \mathrm{GW}$ in 10 years, it is considered highly unlikely that these time-bound targets will be achieved as planned. As a conservative approach, this study discounts the targets and assumes that the total installed capacity would be 3 GW by 2025 and 8 GW by 2030.

40. To predict the maximum possible surplus hydropower that would potentially be available for hydrogen production, it is necessary to conduct a comprehensive and in-depth analysis involving modeling. This, however, is beyond the scope of this short paper which aims to conduct a preliminary rough estimate to produce ballpark figures relating to hydrogen potentials in Nepal. Its overarching objective is to inform relevant stakeholders and facilitate consultation and discussion, which would be possibly followed by more critical investigation into this topic. From this perspective, it is considered appropriate to take a simplified approach by making reference to existing literature relating to hydropower curtailment in Nepal. According to Ale and Bade Shrestha (2008), the share of surplus hydropower that had been curtailed was $46 \%$ in 2004 . And this share was expected to be $48 \%$ by 2020 . A more recent study by the United States National Renewable Energy Laboratory (NREL) on cross-border energy trade between Nepal and India assumed in its model that the curtailment of hydropower in Nepal would be $20 \%$ in Base case (total hydropower capacity 2,840 MW by 2022) and $45 \%$ in High-Build case (total hydropower capacity 4,552 MW by 2022) under the business-as-usual (BAU) scenario featuring high hurdle rate representing economic barriers to electricity export from Nepal to India (McBennett et al. 2019). The High-Build case under the BAU was estimated to have substantially higher curtailment percentage because the additional installed capacity, despite its lower cost, would be underutilized due to the lack of demand for added energy within Nepal, physical transmission constraints, and low export potential with economic viability. It can be derived from NREL's model assumptions that the capacity factors of Base case and High-Build case are $49 \%$ and $34 \%$, respectively. Without curtailment, the capacity factors of Base case and High-Build case would have been $62 \%$ and $61 \%$, respectively.

41. Taking the above into consideration, this paper assumes that, for the study period of 2025 to 2030 , the capacity factor of hydropower plants would be $60 \%$ assuming no curtailment, namely, the maximum possible electricity generation scenario. On this basis, three hypothetical scenarios featuring three curtailment levels are defined, i.e. 20\%, 30\% and 40\%. Under each scenario, the amount of surplus hydropower over the period of 2025 to 2030 is calculated accordingly. Further, the annual hydrogen production is estimated by applying a hydrogen production efficiency to the annual available surplus hydropower. This production efficiency is taken as $50 \mathrm{kWh} / \mathrm{kgH}_{2}$ for 2025 and is assumed to remain constant for simplicity. ${ }^{3}$ The calculation is shown in Table 2.

\footnotetext{
It was estimated by IEA that "producing all of today's dedicated hydrogen output $\left(69 \mathrm{MtH}_{2}\right)$ from electricity would result in an electricity demand of 3600 TWh" (IEA 2019d, p. 43). This is equivalent to a production efficiency of $52 \mathrm{kWh} / \mathrm{kgH}_{2}$ $\left(3,600 \mathrm{TWh} / 69 \mathrm{MtH}_{2}=52 \mathrm{kWh} / \mathrm{kgH}_{2}\right)$. IRENA predicted that the efficiency of ALK would enhance from $51 \mathrm{kWh} / \mathrm{kgH}_{2}$ in 2017 to $49 \mathrm{kWh} / \mathrm{kgH}_{2}$ in 2025, and that of PEM would enhance from $58 \mathrm{kWh} / \mathrm{kgH}_{2}$ in 2017 to $52 \mathrm{kWh} / \mathrm{kgH}_{2}$ in 2025.
} 
Table 2: Calculation of Hydrogen Production from Surplus Hydropower

\begin{tabular}{|c|c|c|c|c|c|c|c|}
\hline & Variable & 2025 & 2026 & 2027 & 2028 & 2029 & 2030 \\
\hline A & Total installed capacity (GW) & 3 & 4 & 5 & 6 & 7 & 8 \\
\hline B & Capacity factor without curtailment (\%) & & & $60 \%$ & & & \\
\hline $\mathrm{C} 1$ & Curtailment-Scenario 1 & & & $20 \%$ & & & \\
\hline $\mathrm{C} 2$ & Curtailment-Scenario 2 & & & $30 \%$ & & & \\
\hline C3 & Curtailment-Scenario 3 & & & $40 \%$ & & & \\
\hline D & Hydrogen production efficiency $\left(\mathrm{kWh} / \mathrm{kgH}_{2}\right)$ & & & 50 & & & \\
\hline E1 & Hydrogen production-Scenario $1\left(\mathrm{MtH}_{2}\right)$ & 0.06 & 0.08 & 0.11 & 0.13 & 0.15 & 0.17 \\
\hline E2 & Hydrogen production-Scenario $2\left(\mathrm{MtH}_{2}\right)$ & 0.10 & 0.13 & 0.16 & 0.19 & 0.22 & 0.25 \\
\hline E3 & Hydrogen production-Scenario $3\left(\mathrm{MtH}_{2}\right)$ & 0.13 & 0.17 & 0.21 & 0.25 & 0.29 & 0.34 \\
\hline
\end{tabular}

$\mathrm{GW}=$ gigawatt, $\mathrm{kgH}_{2}=$ kilogram of hydrogen, $\mathrm{kWh}=$ kilowatt hour, $\mathrm{MtH}_{2}=$ million tons of hydrogen .

Source: Authors' calculation.

42. With hydrogen produced from surplus hydropower per year, the potential electricity that can be regenerated from hydrogen through CCGT or fuel cell per year can be estimated using the previously discussed factor of $1 \mathrm{~kg}$ hydrogen producing $20 \mathrm{kWh}$ electricity. As a result, annual electricity generation from hydrogen over the period of 2025-2030 ranged from 1,261 GWh to 3,364 GWh under Scenario 1. With the increase of curtailment level, the surplus hydropower available for hydrogen production increases accordingly. Under Scenario 3 where the curtailment level is the highest, the total quantity of re-electrification is expected to reach $5,000 \mathrm{GWh}$ by 2028 , exceeding the total electricity generation by all existing hydropower plants in Nepal in 2018. Meanwhile, for a given year, the increase of curtailment level is accompanied with the decrease of quantity of hydropower-Scenario 2 is $12.5 \%$ less than Scenario 1 and Scenario 3 is 25\% less than of Scenario 1 (Figure 24).

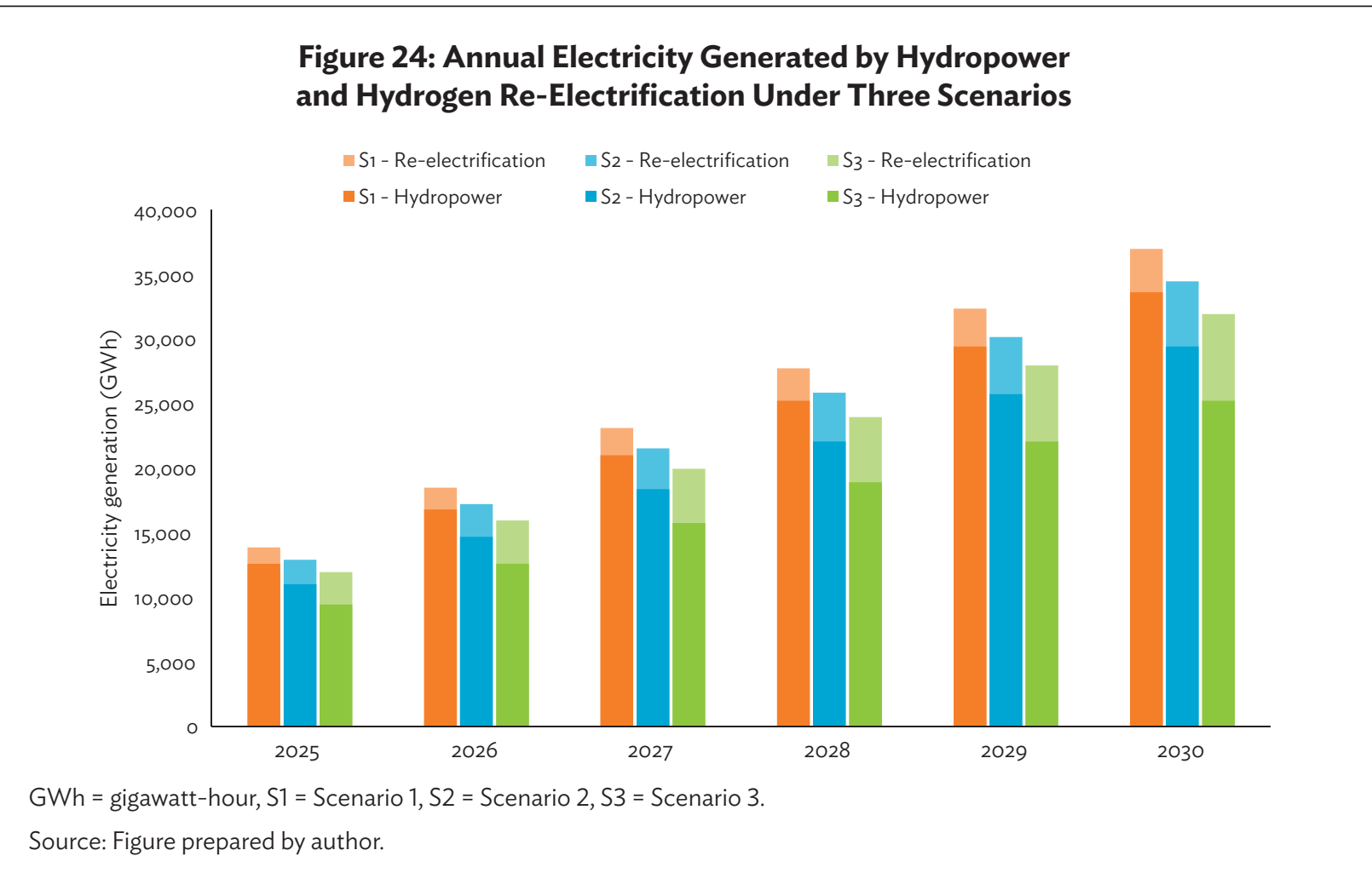


43. It is useful to evaluate the magnitude of the hydrogen re-electrification in the context of future electricity demand forecasted by NEA (NEA 2019). Under any given scenario of curtailment, the planned expansion of installed capacity of hydropower, from $3 \mathrm{GW}$ by 2025 to $8 \mathrm{GW}$ by 2030, leads to a generally ascending trend of the ratio of re-electrification to total forecasted electricity demand of Nepal (Figure 25). The trendline bends slightly downwards because the ratio is a function of both annual addition of new capacity and annual increase of electricity demand. The former is assumed by this study to increase linearly, from $3 \mathrm{GW}$ by 2025 to $8 \mathrm{GW}$ by 2030, whereas the latter is forecasted by NEA to increase at an accelerated rate over the same period. For a given year, a higher curtailment results in a higher ratio, provided that all available surplus hydropower is utilized for producing hydrogen. By 2030 , with a curtailment level of $40 \%$, the quantity of hydrogen re-electrification is equivalent to almost $20 \%$ of total forecasted electricity demand. Overall, the above positive results tend to suggest that the "hydropower-to-power" pathway may produce a considerable quantity of electricity through re-electrification of stored hydrogen, thereby having large potential to contribute to meet part of the electricity demand during dry season in Nepal.

44. For the "hydropower-to-mobility" pathway in Nepal, hydrogen produced from surplus hydropower shown in Table 2 can be used to power FCEVs. Empirical evidences show that the fuel economies for FCEVs are $0.01 \mathrm{kgH}_{2} / \mathrm{km}$ for cars and $0.08 \mathrm{kgH}_{2} / \mathrm{km}$ for buses (Hydrogenics 2019). Official statistics from the Government of Nepal shows that there were a total of 154,433 cars (including jeeps and vans) and 12,617 buses in Nepal by the end of FY2018 (Department of Transport Management 2019). Assuming that annual driving distances are $15,000 \mathrm{~km}$ for cars and $30,000 \mathrm{~km}$ for buses, it can be calculated that if all cars and buses in Nepal are to be converted to FCEVs and start to consume hydrogen by 2025 , which is a highly unlikely extreme scenario in practice, the total demand for hydrogen in 2025 would be around $0.053 \mathrm{MtH}_{2}$, accounting for $84 \%$ of total available hydrogen in 2025 under

Figure 25: Annual Electricity Generation from Hydrogen and its Share in Forecasted Electricity Demand

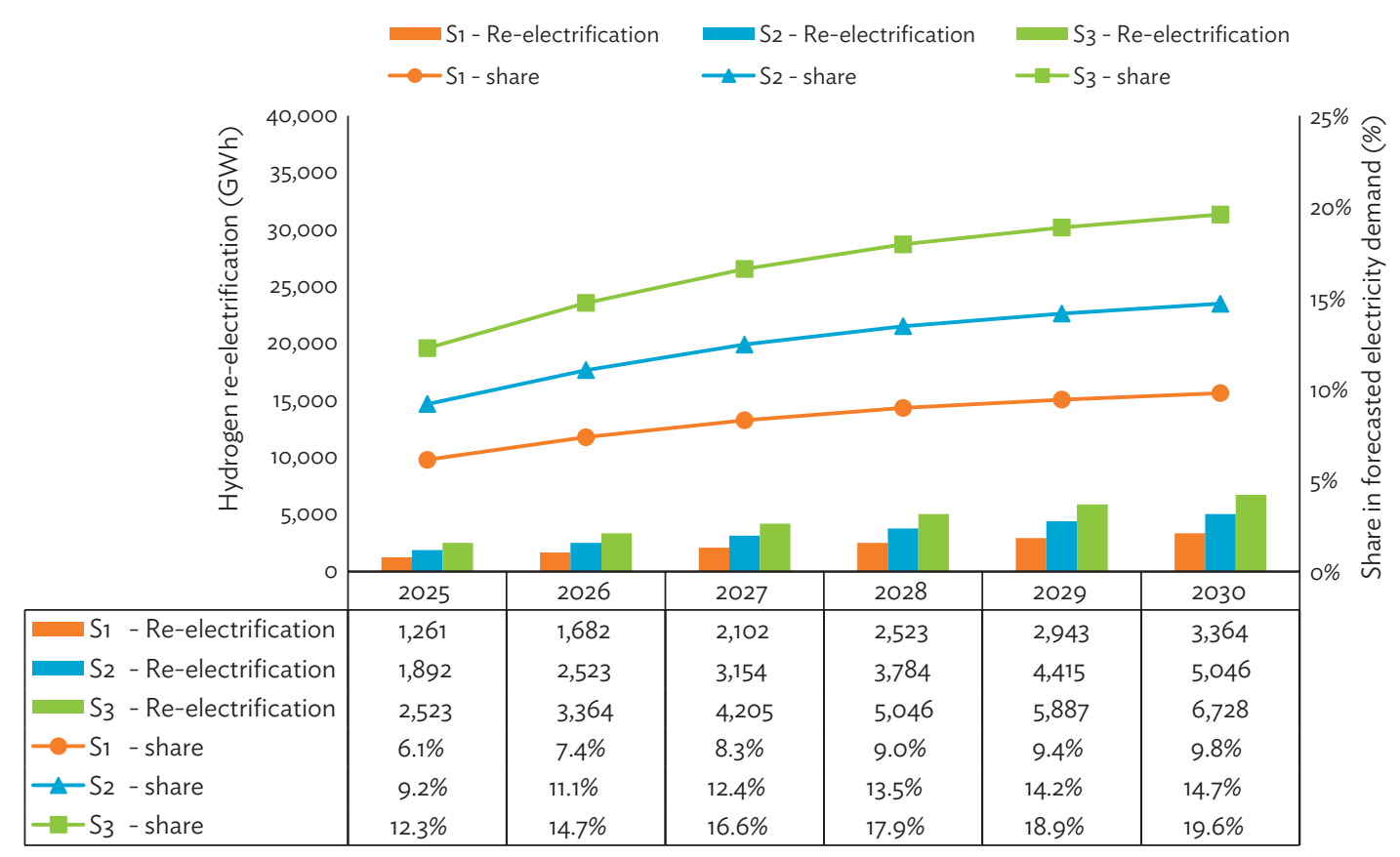

GWh = gigawatt-hour, S1 = Scenario 1, S2 = Scenario 2, S3 = Scenario 3.

Source: Figure prepared by author. 
Scenario 1 which has hydropower curtailment level of $20 \%$. If the target is to electrify $20 \%$ of cars and buses, as set in announced policies by the Government of Nepal, then this demand for hydrogen from the transport sector will decrease to $17 \%$. It will further decrease to $8 \%$ if hydropower curtailment level rises to $40 \%$ under Scenario 3.

45. While hydrogen demand from the transport sector is relatively low, it is worth noting that the predicted electrification of $20 \%$ of Nepal's transport sector may still be an overly optimistic scenario that is highly unlikely to materialize over the short term. Despite the supportive fiscal environment featuring reduced customs tax on electric vehicles and VAT exemption (Ministry of Finance 2016), there is a lack of proactive financial support in the form of government subsidies and financing mechanisms to bring down the unreasonably elevated price of electric vehicles in the Nepali market, accelerate investments in electric vehicle infrastructure, and incentivize switching to electric vehicles in the transport sector. Moreover, the fact that current customs tax on petrol and diesel vehicles generate a significant share of total government tax revenue have institutional implications for potential government support to the desired widespread adoption of electric vehicles (Global Green Growth Institute 2018).

46. Hence, it remains largely unknown when and how much the potentially available hydrogen would be utilized to power vehicles in Nepal. From this perspective, it is considered reasonable and feasible to take both "hydropower-to-power" and "hydropower-to-mobility" pathways in parallel as the latter has minimal demand on hydrogen quantity.

\section{CONCLUDING REMARKS AND NEXT STEPS}

47. Although Nepal has rich hydropower resources, it suffers power supply constraints, particularly during dry season. With hydrogen recently emerging as a promising solution to worldwide energy system, it is worthwhile exploring the potential of hydrogen application for the unique context of Nepal where surplus electricity generated by hydropower during wet season-which otherwise would have been curtailed-can potentially be converted to hydrogen for electricity regeneration to meet the demand during dry season and/or electrifying and decarbonizing its major energy end-use sectors such as the transport sector. This paper was prepared as an attempt to explore the prospect of hydrogen production and utilization in Nepal. Preliminary results based on rough estimates are encouraging. Under a hypothetical scenario where the hydropower curtailment level is $40 \%$ and the expansion of hydropower portfolio is conservatively estimated based on the White Paper, the "hydropower-to-power" pathway has the potential of contributing $12.3 \%-19.6 \%$ of total forecasted electricity demand of Nepal for the years 2025-2030. As an alternative hydrogen value chain, the "hydropower-to-mobility" pathway, assuming $20 \%$ of vehicles will be electrified as planned by the government, would only consume less than $8 \%$ of total available hydrogen produced from surplus hydropower. This suggests the potential feasibility of taking both pathways in parallel.

48. It is acknowledged that the cost and potential estimates in this paper have been arrived at without carrying out sophisticated modeling and analysis or extensive stakeholder consultation. However, instead of producing accurate quantitative projection, this study is aimed at presenting a high-level big-picture perspective with indicative ballpark figures expected to be useful in raising the awareness of policy makers and relevant stakeholders. Moreover, despite all uncertainties associated with the estimates, a strategically significant value of hydrogen in Nepal's energy sector is its potential contribution to addressing Nepal's energy security issues, which are characterized by heavy dependence on energy imports, inadequate storage, and extremely limited diversity of domestic electricity generation sources (Water and Energy Commission Secretariat 2013; ADB 2017; Nepal and Paija 2019). The World 
Energy Trilemma Index 2019 (World Energy Council 2019b) ranked the energy system of Nepal 117th out of the total 128 countries or regions evaluated. With specific regard to energy security, Nepal was ranked 126 th, obtaining the lowest score in energy security among countries in Asia covered by the ranking. More critically, from 2000 to 2019, the energy security score of Nepal has exhibited a continuously declining trend, suggesting increasing severity of energy security issues of the country (World Energy Council 2019a). Arguably, hydrogen production and utilization, which can take advantage of complementary seasonal patterns of hydropower supply and electricity demand in Nepal, is expected to have a promising potential to provide an alternative solution to address issues relating to electricity import and energy storage of Nepal. This strongly justifies further investigation into exploring hydrogen development opportunities in Nepal and possibly in other ADB DMCs with rich indigenous energy resources, and at the same time facing similar challenges in their energy sectors.

49. As next steps, it is suggested to take forward the preliminary findings of this study and undertake more holistic and in-depth studies to evaluate the technical feasibility and economic viability of developing a hydrogen value chain in Nepal. Findings from further studies will contribute to closing the gaps in knowledge and analysis, thereby better informing and engaging key stakeholders whose collective efforts are critical to create an enabling environment for exploring "hydropower-to-X" potentials in Nepal. Main aspects to study are suggested to include, among others:

- developing an enhanced understanding of current cost levels and future cost-reduction potential of different types of electrolyzers and their potential capabilities of operating partload based on the availability of variable renewable energy;

- estimating potential quantity of the otherwise curtailed surplus hydropower during wet season that may potentially be utilized for electrolysis in the context of Nepal's announced targets and plans of hydropower capacity expansion and the total forecasted electricity demand over the short- to medium-term;

- developing an enhanced understanding of the energy system benefits of hydrogen production from electrolysis, in particular the economics of seasonal storage of hydrogen for re-electrification during dry season and electrolyzers providing ancillary services such as adding demand-side flexibility to power system in the specific context of Nepal;

- taking stock of existing vehicles with respect to key metrics such as (i) registration number, (ii) age distribution, (iii) fuel economy and annual driving distance, (iv) forecasting future transport demand, (v) updating the estimate of hydrogen value chain potential in transport sector, and (vi) conducting cost analysis on FCEVs in the specific context of Nepal where prices of EVs are high;

- in parallel with the "hydropower-to-power" and "hydropower-to-mobility" pathways, identifying the opportunities and assessing potentials of other pathways potentially relevant to Nepal's economy, e.g., "hydropower-to-fuel" and "hydropower-to-industry; and"

- evaluating options of hydrogen supply chain relevant to various potential "hydropower-to-X" pathways in Nepal. Possible options may be large-scale off-grid hydrogen projects directly connected to hydropower plants, thereby having low-cost 100\% renewable hydrogen but relatively low electrolyzer utilization rate and possibly long supply chain leading to higher hydrogen cost. There may also be on-site hydrogen production facilities that are gridconnected and close to centers of hydrogen demand, thereby having low supply chain costs and higher electrolyzer utilization rate but not having 100\% renewable hydrogen, and possibly being subject to higher power transmission costs. 


\section{REFERENCES}

Ale, B., and S. Bade Shrestha. 2008. Hydrogen Energy Potential of Nepal. International Journal of Hydrogen Energy. 33(15). pp. 4030-4039. doi: 10.1016/j.ijhydene.2008.04.056.

Alshehri, F., V. G. Suárez, J. L. Rueda Torres, A. Perilla, and M.A.M.M. van der Meijden. 2019. Modelling and Evaluation of PEM Hydrogen Technologies for Frequency Ancillary Services in Future Multi-Energy Sustainable Power Systems, Heliyon, 5(4). doi: 10.1016/j.heliyon.2019.e01396.

Andersson, J., and S. Grönkvist. 2019. Large-Scale Storage of Hydrogen. International Journal of Hydrogen Energy. 44(23). pp. 11901-11919. doi: 10.1016/j.ijhydene.2019.03.063.

Asian Development Bank (ADB). 2013. Energy Outlook for Asia and the Pacific. https://www.adb.org/ sites/default/files/publication/30429/energy-outlook.pdf.

2017. Nepal Energy Sector Assessment, Strategy, and Road Map. https://www.adb.org/sites/default/ files/publication/356466/nepal-energy-assessment-road-map.pdf.

BloombergNEF. 2019. Hydrogen: The Economics of Storage - Storing Clean Molecules at Scale.

CarbonBrief. 2019. Renewable Hydrogen 'Already Cost Competitive', say researchers. https://www. carbonbrief.org/renewable-hydrogen-already-cost-competative-say-researchers.

Department of Transport Management. 2019. Registered Vehicles Till Fiscal Year 2017/18. https://dotm. gov.np/uploads/files/vehicles data till 2074-75.pdf.

DNV GL (Det Norske Veritas and Germanischer Lloyd). 2019. Hydrogen in the Electricity Value Chain. https://www.dnvgl.com/publications/hydrogen-in-the-electricity-value-chain-141099.

Global Green Growth Institute. 2018. National Action Plan for Electric Mobility:Accelerating Implementation of Nepal's Nationally Determined Contribution. https://gggi.org/site/assets/uploads/2018/07/GGGINepal_Action-Plan-for-Electric-Mobility.pdf.

Goodall, C. 2017. Hydrogen Made by the Electrolysis of Water is Now Cost-Competitive and Gives Us Another Building Block for the Low-Carbon Economy. https:/www.carboncommentary.com/blog/2017/7/5/ hydrogen-made-by-the-electrolysis-of-water-is-now-cost-competitive-and-gives-us-anotherbuilding-block-for-the-low-carbon-economy.

Government of Nepal, Ministry of Energy Water Resources and Irrigation. 2018. Energy, Water Resources and Irrigation Sector's Current Status and Roadmap for Future. http://moewri.gov.np/images/category/ White-Paper-2075-with-Annex02.pdf

Government of Nepal, Ministry of Finance. 2016. Budget Speech of Fiscal Year 2016/17. https://mof.gov.np/ uploads/document/file/Budget_Speech_final_2016_20160602105902.pdf.

Government of Nepal, Ministry of Physical Infrastructure and Transport. 2015. National Sustainable Transport Strategy (NSTS) for Nepal (2015-2040). Available at: http://www.uncrd.or.jp/content/ documents/3377Background Paper -EST Plenary Session 2 (No. 1).pdf. 
Government of Nepal, Ministry of Population and Environment. 2016. Nationally Determined Contributions. https://www4.unfccc.int/sites/ndcstaging/PublishedDocuments/Nepal First/Nepal First NDC.pdf.

2017. Nepal's GHG Inventory-For Third National Communication to the UNFCCC. http://mofe. gov.np/noticefile/Nepal's GHG Inventory-Final_version_1562308551.pdf.

Hydrogenics. 2019. Renewable Hydrogen Solutions. http://www.hydrogenics.com/wp-content/uploads/ Renewable-Hydrogen-Brochure.pdf.

International Energy Agency (IEA). 2015. Technology Roadmap: Hydrogen and Fuel Cells. doi: 10.1007/ SpringerReference_7300.

2017. Global Trends and Outlook for Hydrogen. doi: ISBN-13: 978-1-945951-07-7.

2019a. Cost-Competitive Hydrogen Fuel Cell Systems for FCEVs. https://www.iea.org/topics/ innovation/transport/gaps/cost-competitive-hydrogen-fuel-cell-systems-for-fcevs.html.

2019b. Data and Statistics. https://www.iea.org/data-and-statistics.

2019c. Key World Energy Statistics 2019. https://webstore.iea.org/download/direct/2831?file Name=Key_World_Energy_Statistics_2019.pdf.

2019d. The Future of Hydrogen: Seizing Today's Opportunities. https://webstore.iea.org/download/ direct/2803?fileName=The_Future_of_Hydrogen.pdf.

International Renewable Energy Agency (IRENA). 2018. Hydrogen From Renewable Power: Technology Outlook for the Energy Transition. https://www.irena.org/-/media/Files/IRENA/Agency/Publication/2018/ Sep/IRENA_Hydrogen_from_renewable_power_2018.pdf.

2019a. Hydrogen: A Renewable Energy Perspective. https://www.irena.org/-/media/Files/IRENA/ Agency/Publication/2019/Sep/IRENA_Hydrogen_2019.pdf.

2019b. Innovation Landscape for a Renewable-Powered Future: Solutions to Integrate Variable Renewables. https://www.irena.org/-/media/Files/IRENA/Agency/Publication/2019/Feb/IRENA_Innovation_ Landscape_2019_report.pdf.

2019c. Navigating the Way to a Renewable Future: Solutions to Decarbonise Shipping. https:// www.irena.org/-/media/Files/IRENA/Agency/Publication/2019/Sep/IRENA_Renewable_Shipping_ Sep_2019.pdf.

McBennett, ,A. Rose, D. Hurlbut, D. Palchak, and J. Cochran. 2019. Cross-Border Energy Trade between Nepal and India: Assessment of Trading Opportunities. Golden, CO: National Renewable Energy Laboratory. NREL/TP-6A20-72066. https://www.nrel.gov/docs/fy19osti/72066.pdf.

Nepal, , and N. Paija. 2019. Energy Security, Electricity, Population and Economic Growth: The Case of a Developing South Asian Resource-Rich Economy. Energy Policy. Elsevier. 132(C). pp. 771-781. doi: 10.1016/j.enpol.2019.05.054.

Nepal Electricity Authority (NEA). 2018. Annual Report 2017/18. https://www.nea.org.np/admin/assets/ uploads/supportive_docs/90599295.pdf. 
2019. Annual Report 2018/19. https://www.nea.org.np/admin/assets/uploads/supportive_docs/ annual_report_2076.pdf.

National Renewable Energy Laboratory (NREL). 2016. Economic Assessment of Hydrogen Technologies Participating in California Electricity Markets, National Renewable Energy Laboratory. https://www.nrel.gov/ docs/fy16osti/65856.pdf.

Oxford Policy Management. 2017. Energy in Nepal. https://assets.publishing.service.gov.uk/ media/5a2696fae5274a75088c42b6/Line_36_-_EEG_Pre-South_Asia_Policy_Workshop_ Report.29.09.2016.pdf.

Proost, J. 2019. State-of-the Art CAPEX Data for Water Electrolysers, and their Impact on Renewable Hydrogen Price Settings. International Journal of Hydrogen Energy. 44(9). pp. 4406-4413. doi: 10.1016/j. ijhydene.2018.07.164.

Reuß, , T. Grube, M. Robinius, P. Preuster, P. Wasserscheid, and D. Stolten. 2017. Seasonal Storage and Alternative Carriers: A Flexible Hydrogen Supply Chain Model. Applied Energy. 200. pp. 290-302. doi: 10.1016/j.apenergy.2017.05.050.

Rocheleau, , and M. Ewan. 2016. Hydrogen Energy Systems as a Grid Management Tool. https://www. hydrogen.energy.gov/pdfs/review16/mt008_ewan_2016_o.pdf.

Shakya, and R. Shrestha. 2011. Transport Sector Electrification in a Hydropower Resource Rich Developing Country: Energy Security, Environmental and Climate Change Co-Benefits, Energy for Sustainable Development. 15(2). pp. 147-159. doi: 10.1016/j.esd.2011.04.003.

Shell. 2017. Shell Hydrogen Study: Energy of the Future? Sustainable Mobility through Fuel Cells and H2. https://www.shell.com/energy-and-innovation/new-energies/hydrogen/_jcr_content/par/ keybenefits_150847174/link.stream/1496312627865/6a3564d61b9aff43e087972db5212be68d1fb 2e8/shell-h2-study-new.pdf.

Shiva Kumar, , and V. Himabindu. 2019. Hydrogen Production by PEM Water Electrolysis-A Review. Materials Science for Energy Technologies. 2(3). pp. 442-454. doi: 10.1016/j.mset.2019.03.002.

Shrestha, H. 2017. Facts and Figures About Hydropower Development in Nepal. Hydro Nepal: Journal of Water, Energy and Environment. 20. pp. 1-5. doi: 10.3126/hn.v20i0.16480.

Thyssenkrupp. 2019. Hydrogen from Large-Scale Electrolysis: Efficient Solutions for Sustainable Chemicals and Energy Storage. https://13qmi8c46i38w.cloudfront.net/media/ UCPthyssenkruppBAISUhdeChlorineEngineers/assets.files/products/water_electrolysis/ tk_19_0820_hydrogen_broschuere_2019_03.pdf.

Water and Energy Commission Secretariat. 2013. National Energy Strategy of Nepal. https://www.wecs. gov.np/uploaded/National-Energy-Strategy-of-Nepal-2013.pdf.

2017. Electricity Demand Forecast Report (2015-2040). https://www.wecs.gov.np/uploaded/ Electricity-Demand-Forecast-Report-2014-2040.pdf.

World Bank. 2019a. Nepal Energy Infrastructure Sector Assessment. http://documents.worldbank.org/ curated/en/592481554093658883/pdf/Nepal-Energy-Infrastructure-Sector-Assessment.pdf. 
2019b. World Development Indicators. http://databank.worldbank.org/data/views/variable Selection/selectvariables.aspx?source=world-development-indicators.

World Energy Council. 2019a. Country Profile-Nepal. https://trilemma.worldenergy.org/reports/ countryProfile/2019/Nepal.pdf.

2019b. World Energy Trilemma Index 2019. https://trilemma.worldenergy.org/reports/main/ 2019/2019 Energy Trilemma Index.pdf. 


\section{A Study on the Prospect of Hydropower to Hydrogen in Nepal}

This paper explores the prospect of deploying hydrogen to address shortage of electricity and fuel supply in Nepal. It also serves as a baseline for further hydrogen opportunities in countries with abundant renewable resources and facing energy-related challenges. Nepal faces electricity and fuel supply shortage despite its abundant hydropower resources that have remained largely undeveloped. The hypothesis is that surplus hydropower capacity during the wet season is not utilized due to demand shortage. The study in this paper focuses on hydrogen deployment in Nepal, where it may be produced during the wet season. It is expected to raise awareness among policymakers on further hydrogen opportunities in the country.

\section{About the Asian Development Bank}

ADB is committed to achieving a prosperous, inclusive, resilient, and sustainable Asia and the Pacific, while sustaining its efforts to eradicate extreme poverty. Established in 1966, it is owned by 68 members -49 from the region. Its main instruments for helping its developing member countries are policy dialogue, loans, equity investments, guarantees, grants, and technical assistance. 